\title{
Natural tracers in recent groundwaters from different Alpine aquifers
}

\author{
Sybille Kilchmann • H. Niklaus Waber • \\ Aurele Parriaux $\cdot$ Michael Bensimon
}

\begin{abstract}
Groundwater with underground residence times between days and a few years have been investigated over more than 20 years from 487 remote sites located in different aquifer types in the Alpine belt. Analysis of the data reveals that groundwaters evolved in crystalline, evaporite, carbonate, molasse, and flysch aquifers can be clearly distinguished based on their major and trace element composition and degree of mineralisation. A further subdivision can be made even within one aquifer type based on the trace element compositions, which are characteristic for the lithologic environment. Major and trace element concentrations can be quantitatively described by interaction of the groundwater with the aquifer-specific mineralogy along the flow path. Because all investigated sites show minimal anthropogenic influences, the observed concentration ranges represent the natural background concentrations and can thus serve as a "geo-reference" for recent groundwaters from these five
\end{abstract}

Received: 5 November 2002 / Accepted: 22 May 2004

Published online: 25 September 2004

(C) Springer-Verlag 2004

S. Kilchmann (

Laboratory of Engineering and Environmental Geology,

Federal Institute of Technology,

Lausanne, Switzerland

e-mail: Sybille.Kilchmann@buwal.admin.ch

Tel.: +41-31-3247691

H. N. Waber

Rock-Water Interaction, Institute of Geological Sciences, University of Bern,

Baltzerstrasse 1, 3012 Bern, Switzerland

A. Parriaux

Laboratory of Engineering and Environmental Geology,

Federal Institute of Technology,

1015 Lausanne, Switzerland

M. Bensimon

Laboratory of Engineering and Environmental Geology,

Federal Institute of Technology,

1015 Lausanne, Switzerland

Present address:

S. Kilchmann, Water Protection and Fisheries Division, Swiss Agency for the Environment, Forests and Landscape, 3003 Bern, Switzerland aquifer types. This "geo-reference" is particularly useful for the identification of groundwater contamination. It further shows that drinking water standards can be grossly exceeded for critical elements by purely natural processes.

Resumen Durnate más de 20 años se ha investigado aguas subterráneas con una residencia subterránea con una duración de días a varios años en 487 puntos remotos localizados en diferentes tipos de acuíferos en la cadena alpina. El análisis de los datos revela que las aguas subterráneas que han evolucionado dentro de acuíferos cristalinos, evaporíticos, carbonatos, flysch, y molasse se pueden distignuir claramente en base a la composición de sus elementos mayores y marcadores y al grado de minerlización. Asimismo es posible hacer una subdivisión más específica incluso dentro de un tipo de acuífero en base a las composiciones de los elementos marcadores los cuales soncaracterísticos del ambiente litológico. Las concentraciones de los elementos marcadores se pueden describir cuantitativamente por la interacción de las aguas subterráneas con la mineralogía específica del acuífero a lo largo del trayecto del flujo. Puesto qze todos los puntos investigados muestran mínimas influencias antropogénicas, los rangos deconcentraciones observados representan las concentraciones delescenario natural y, por tanto, pueden servir como georeferencia para aguas subterráneas recientes que forman parte de estos cinco tipos de acuíferos. Esta georeferencia es particularmente útil para la identificcación de contaminación de aguas subterráneas. Asimismo muestra que los estándares de agua potable pueden mostrar excesos en elementos críticos por procesos puramente naturales.

Résumé L'eau souterraine ayant résidé sous la surface du sol entre quelques jours et quelques années a été étudiée sur une période de plus de 20 ans à partir de 487 sites éloignés situés dans différents types d'aquifères de la ceinture alpine. L'analyse des données révèle que l'eau qui a évoluée dans des aquifères cristallins, évaporitiques, carbonatés, molassiques et composés de flysch, peut être facilement différenciée sur la base de sa composition en éléments majeurs et traces, ainsi que par son degré de minéralisation. Une subdivision supplémentaire peut être apportée à l'intérieur même d'un type d'aquifère en se basant sur la composition des éléments traces, lesquels 
sont caractéristiques de l'environnement lithologique. La concentration en éléments majeurs et traces peut être expliquée quantitativement par l'interaction de l'eau souterraine avec la composition minéralogique spécifique de l'aquifère le long des lignes d'écoulement. Puisque la majorité des sites étudiés ne montrent que très peu d'influences anthropogéniques, le registre de concentrations observées représente la concentration de fond naturelle et peut ainsi servir comme géo-référence pour les eaux souterraines récentes dans ces cinq types d'aquifères. Ces géo-références sont particulièrement utiles pour l'identification de la contamination des eaux souterraines. Par ailleurs, cela démontre que les standards d'eau potable peuvent être excédés pour certains éléments en raison de processus purement naturels.

Keywords Natural groundwater composition - Natural tracer elements - Rock-water interaction - Geochemical modelling · Groundwater observation networks

\section{Introduction}

The large increase in drinking water consumption in the past few decades demands more rigorous groundwater quality controls and a better understanding of naturally occurring groundwater mineralisation processes with respect to trace elements. In the past, quality control of shallow drinking water supplies focused mainly on the composition of major elements and microbiological aspects. Studies on trace element compositions of such resources were restricted to anthropogenic point source (e.g. industrial sites) and non-point source pollution (e.g. agriculture) investigations (Moore and Ramamoorthy 1984; Salomons and Förstner 1984; Adriano 1986; Nriagu 1991; Markert and Friese 2000). Systematic research on natural background concentrations of trace elements in recent groundwaters was limited until the increased awareness of groundwater quality led to a more systematic approach, and to the development of national groundwater-monitoring networks in several countries (e.g. The Netherlands: Frapporti et al. 1996; Switzerland: BUWAL 1998; Greber et al. 2002). Knowledge of natural contributions to trace element contents and fluxes in recent groundwaters is necessary for groundwater quality assessment: For example in assessing the potential hazards of naturally mobilised arsenic in groundwaters of the Bengal delta plain (Sahu et al. 2001) or in southern Switzerland (Pfeifer et al. 1995, 2000). It also serves as a base for drinking water regulation issues for geologically different environments and, if required, for groundwater treatment strategies.

The projects AQUITYP and AQUISOL conducted at the Federal Institute of Technology in Lausanne, Switzerland (EPFL, Laboratory of Engineering and Environmental Geology), investigated trace element behaviour in recent groundwaters and soils in different lithologic environments in the Alpine belt. The AQUITYP project (Parriaux et al. 1990a) focused on the chemistry of recent groundwaters from the major aquifer types in the Alpine belt by establishing a groundwater-monitoring network with over 500 springs and wells sampled over the past 20 years. Detailed studies concentrated on recent groundwaters in crystalline rocks (Dubois 1993), carbonate sediments (Dematteis 1995), evaporite rocks (Mandia 1993), as well as molasse and flysch sediments (Hesske 1995; Hesske et al. 1997; Basabe 1993). Several specific trace elements have been identified in aquifers based on statistical evaluation of the groundwater and aquifer lithology data combined with experimental data. These elements are referred to as natural tracers. Trace element cycling in soil ecosystems, developed on the different aquifer-rock types, was the main focus of the AQUISOL project (Atteia 1992, 1994; Dalla Piazza 1996).

The present study presents a compilation and a process-orientated interpretation of the data gathered within these two projects. Concentration ranges for natural major and trace elements - a so-called "geo-reference" is deduced for recent groundwaters from the different aquifer types, and the relevant mineralisation processes and physical-chemical conditions are characterised by applying geochemical modelling strategies.

\section{Selection of Representative Catchments}

Catchments selected for the AQUITYP project had to fulfil certain geologic, hydrogeologic and environmental criteria (Parriaux et al. 1990a). An attempt was made to select aquifers that consist of a single lithologic unit within a simple tectonic context, to exclude the influence of other lithologic units. In addition, springs had to be located in remote regions with none or only minimal agricultural activity to minimise anthropogenic impacts. Waters from very superficial flow systems were excluded by choosing only perennial springs. Preference was given to spring waters emerging directly from the rock to avoid contamination by materials used in technical installations. Variations in the natural groundwater chemistry in a given aquifer type were traced by analysing most sampling sites twice, with 32 representative sites being monitored over several years.

\section{Methods}

All chemical analyses were performed at the Laboratory of Engineering and Environmental Geology. During data acquisition over 20 years the analytical methods for groundwater chemical analysis have continuously been updated (Basabe 1993, Dubois 1993, Mandia 1993, Dematteis 1995, Hesske 1995). A complete synopsis of sampling techniques, sample treatment and analytical methods applied in the AQUITYP project is given in Kilchmann (2001). On-site measurements included discharge $(\mathrm{Q})$, electrical conductivity (EC), water temperature $(\mathrm{T}), \mathrm{pH}$, and redox potential $\left(\mathrm{E}_{\mathrm{H}}\right)$. The groundwa- 
Table 1 Investigated aquifer types in the Alpine region and their typical hydrogeologic characteristics

\begin{tabular}{llll}
\hline Rock type & Lithology & Aquifer type & Predominant groundwater flow \\
\hline Crystalline rocks & Gneiss and granite & Crystalline & Fracture flow \\
Rocks mostly composed & Carbonate rocks & Carbonate karst & Conduit and fracture flow (karst) \\
of soluble minerals & Evaporite rocks & Evaporite karst & \\
Clastic sediments & Molasse rocks & Molasse & Inter-granular and fracture flow \\
& Flysch rocks & Flysch & Fracture flow \\
\hline
\end{tabular}

ter samples were not filtered. Cation and trace element concentrations were performed on acidified $(\mathrm{pH}<2)$ samples by ion chromatography (IC), atomic absorption spectrometry (AAS-FES) and most recently by high resolution inductively coupled plasma source mass spectrometry (HR-ICP-MS). Alkalinity was determined by titration to the methyl-orange endpoint. Dissolved silica and boron were determined by colorimetric methods. A specific electrode was used for fluoride analyses, while all other anions were determined by conventional IC methods.

To enable a comparison of the groundwater chemical data gathered and analysed over such a long time span, rigorous quality control of the entire database was undertaken (Kilchmann 2001). The analytical data were evaluated for overall quality and the comparability of the different analytical methods was examined. The carbonate system and $\mathrm{Ca}$-concentrations were examined for all analyses by geochemical modelling strategies (see below). Filtration tests showed that only the concentrations of dissolved $\mathrm{Fe}$ and $\mathrm{Al}$ appear to be overestimated due to the presence of particulate or colloidal matter in nonfiltered samples, while for major and other trace elements such a contribution lies within the analytical uncertainty. From a total of 1,824 groundwater analyses, 1,674 analyses passed the quality check. Out of these, 1,475 are analyses of recent, tritiated groundwaters with residence times between a few days and about 20 years and were selected for further investigation. The selected data are stored in an electronic database (AQUITYP-DataBase, Kilchmann 2001).

The hydrochemical facies (chemical water type) was determined based on the relative proportions of major anion and cation concentrations following the classification of Jäckli (1970).

The geochemical computer code PHREEQC (Parkhurst and Appelo 1999) with the thermodynamic database WATEQ4F (Ball and Nordstrom 1991) was used to calculate the distribution of aqueous species and mineral saturation indices. Mineral saturation states were only calculated for minerals with fast reaction kinetics, where attainment of equilibrium between the mineral and groundwater within the residence time of the groundwaters is realistic.

To delineate chemical mass transfers occurring between the infiltration of rain water and the discharge of groundwater, mass balance calculations were performed following the inverse modelling strategy by Plummer and Back (1980) and using the geochemical computer code NETPATH (Plummer et al. 1994).

\section{Geologic and Hydrogeologic Setting}

The concentrations of trace elements in recent groundwaters depend on aquifer mineralogy and hydrogeology, and on chemical rock-water interactions. In the design of the groundwater observation networks of the AQUITYP project, the hydrogeologic (Table 1) and the lithologic (Table 2) characteristics of the different aquifer types have been considered (Parriaux et al. 1990 a).

\section{Springs in Crystalline Rocks}

The springs investigated in crystalline rocks are situated in the Mont-Blanc and Aiguilles-Rouges massifs in southwestern Switzerland, and in neighbouring France and Italy (Fig. 1). This Alpine area is characterised by a very steep topography. A large part of the catchment surfaces are situated at altitudes above 2,000 m above sea level and covered by glaciers or bare rock. The studied spring waters discharge at altitudes between $570 \mathrm{~m}$ and 2,080 $\mathrm{m}$ above sea level.

Major rock types of the Mont-Blanc and AiguillesRouges massifs include pre-Mesozoic granite and gneiss series (Table 2). Several episodes of brittle deformation resulted in extensive fracture networks, which act as preferential pathways for groundwater flow. Depending on residence time, contributions to groundwater mineralisation by water from zones of lower permeability (e.g. partially sealed fractures, undisturbed rock matrix) have to be considered. Hydrothermal mineralisation occurring as fracture linings is a widespread occurrence in tectonised zones. Long-term observations of discharge from selected springs revealed strong seasonal fluctuations due to snowmelt during spring and summer, while water temperature and mineralisation showed only small variations. Tracer tests and calculations based on tritium data both suggest very short residence times of the groundwater, in the order of one to two years (Dubois 1993; Maréchal 1998).

\section{Springs in Carbonate Rocks}

Groundwater evolving in carbonate rocks of variable diagenetic and metamorphic overprint was investigated in catchments in the Jura Mountains (France and Switzerland), the Swiss Alps, the Apennines (Italy), the Dinarids (Slovenia), and the Hellenids (Greece) (Fig. 1). The purpose of this large geographic distribution was to cover the lithologic diversity of carbonate rocks of different age and from various sedimentary and tectonic environments (details are given in Dematteis, 1995). 
Table 2 Overview of the mineralogy in the different aquifer types

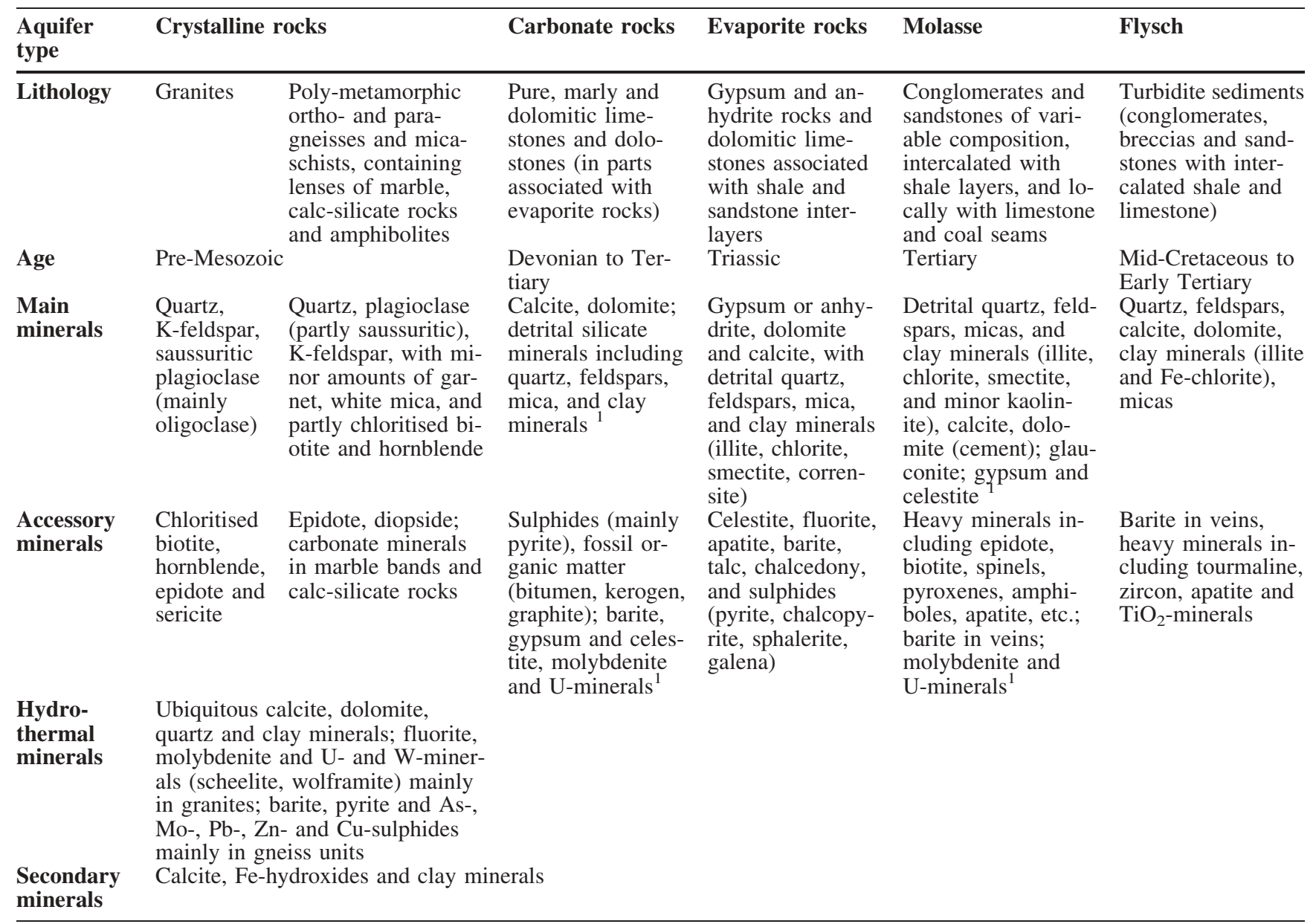

1 depending on sedimentary environment

The investigated springs discharge at altitudes between 1 and $1,550 \mathrm{~m}$ above sea level and their locations vary from near the sea shore to continental. The catchments consist of various carbonate rocks of Devonian to Eocene age (Table 2). The Triassic carbonate sequences of the Alps and the Apennine carbonate rocks can be intimately associated with evaporite rocks. Carbonate karst aquifers are characterised by their conduit porosity (e.g. Ford and Williams 1989; Ford 1998). The overall permeability of carbonate rock aquifers is usually very high and depends on the extent of karst development. By far the largest proportion of groundwater flow occurs through conduits and fissures, while only a small proportion is transmitted through the matrix porosity of the carbonate rock (Atkinson 1975). The mean residence time of karst groundwaters is consequently short, ranging from a few hours to some months (Dematteis 1995 and references therein). The mineralisation of karst waters typically varies strongly in response to seasonal changes in recharge.

\section{Springs in Evaporite Rocks}

Catchments in Triassic evaporite rock series were studied in the Rhone Valley in southwestern Switzerland (Fig. 1), in various tectonic settings (Préalpes, Helvetic and Ultrahelvetic units, and Penninic nappes; see Mandia 1993 for details). This region is characterised by a pronounced alpine topography and the investigated groundwaters discharge at altitudes between $375 \mathrm{~m}$ and 2,200 $\mathrm{m}$ above sea level.

The evaporite sequence (Table 2) is usually strongly deformed and occurs as discontinuous shreds and lenses of variable thickness. Mineralisations containing barite and sulphides are common. Calcium sulphate rocks exhibit a characteristic hydrogeology. While the high solubility of gypsum leads to the development of karst conduits along near-surface fractures, the hydration of an-

Fig. 1 Locations of sampling sites in Switzerland (top, Hydrogeological sketch of Switzerland modified from Federal Office of Water and Geology), a simplified tectonic map of Switzerland showing the major units used (middle, A.-R.: Aiguilles-Rouge and Mont-Blanc massifs, SaM: Subalpine Molasse), and the sampling sites of carbonate groundwaters across Europe (bottom, modified from Dematteis, 1995) 
SWITZERLAND

MAIN AQUIFER TYPES

Unconsolidated aquifers

Porous

Consolidated aquifer

- : Porous, partly fissured

$\square$ Fissured, partly porous

$\equiv$ Fissured

CTarstified

SAMPLING SITES

$\diamond$ Molasse rocks

- Carbonate rocks

* Crystalline rocks

- Evaporate rocks

+ Flysch rocks
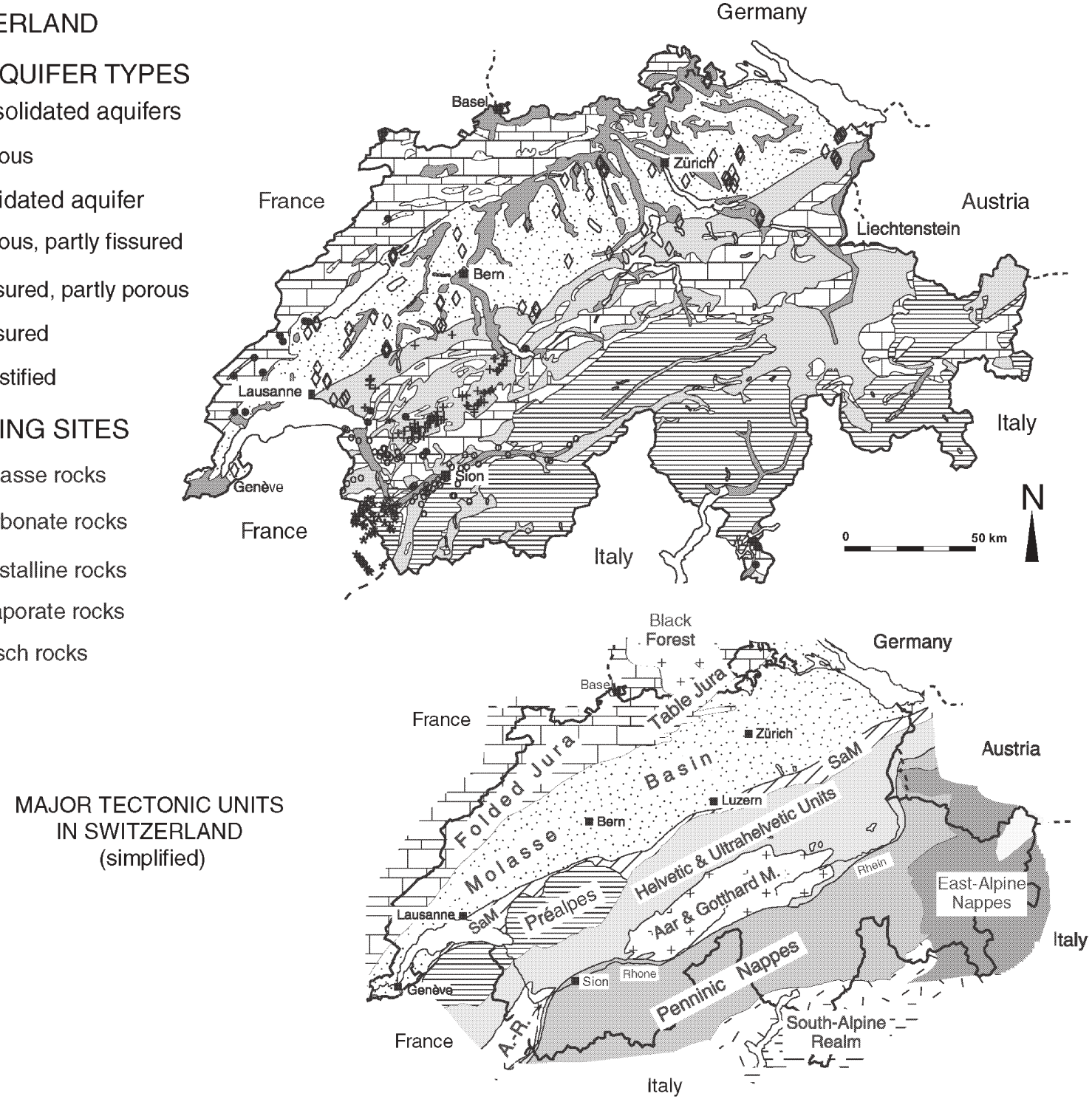

SAMPLING AREAS FOR CARBONATE KARST GROUNDWATERS IN EUROPE

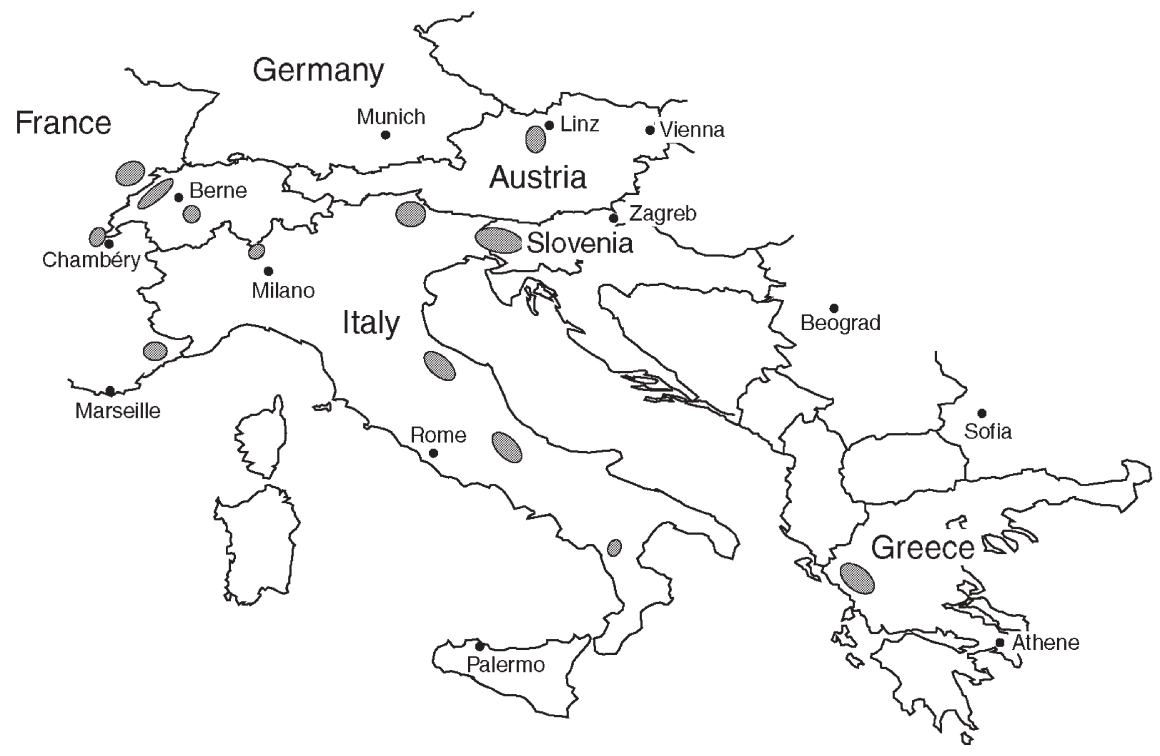


hydrite and the formation of secondary gypsum may seal the porosity farther downgradient where the water approaches equilibrium with gypsum. Therefore, the permeability of such evaporite rocks depends strongly on the geologic-tectonic context, particularly on the thickness of the evaporite formation and on the extent of fracturing (e.g. Parriaux et al. 1990b). In the investigated area, catchments with groundwater recharge and discharge located within evaporite rocks occur only in the Ultrahelvetic tectonic unit inbetween the different Helvetic nappes. For the catchments in other tectonic units, recharge occurs through various other rock types (e.g. carbonates, gneiss, schist) before reaching the evaporite layers. Monitoring of discharge, water mineralisation and temperature of selected springs showed large seasonal fluctuations of discharge combined with opposite variations in the degree of groundwater mineralisation. Tracer tests were used to determine minimum residence times between 22 hours and 4 months (Mandia 1993).

\section{Springs in Molasse Rocks}

The investigated molasse catchments are situated in the Tertiary Molasse Basin between Chambéry (France) and Linz (Austria), with a large majority of the sampling sites being situated in Switzerland (Fig. 1). This area shows a smooth hilly topography and springs are located at altitudes between $340 \mathrm{~m}$ and $1,430 \mathrm{~m}$ above sea level. Catchments are covered by deep soils and rich vegetation.

The Molasse basin consists of marine and freshwater sediment series of variable thickness, resulting from the uplift and erosion of the Alps (Trümpy 1980). The investigated molasse catchments are mainly situated in conglomerate and sandstone formations (Table 2). The rock fragments and heavy mineral assemblages of the conglomerates and sandstones vary on a regional scale and are characteristic for the catchment area. This variation in the mineralogical composition results in typical trace element compositions in molasse groundwaters from different areas. Molasse aquifers are generally characterised by a double porosity. Groundwater can circulate relatively fast along fractures and stratification joints ("fracture flow"), and slowly within intergranular pores ("matrix flow"). Fracture flow dominates in tectonically deformed areas, such as in the Subalpine molasse (Parriaux 1981; Schoepfer 1989). Matrix flow can be dominant in weakly deformed or undeformed areas. All investigated molasse groundwaters contain tritium and residence times range from a few days to several years (Hesske 1995). The observed negative correlation between groundwater discharge and water mineralisation confirms the influence of the residence time on groundwater mineralisation.

\section{Springs in Flysch Rocks}

Springs in flysch rocks were studied in the Swiss Prealps (Fig. 1). The investigated springs are located between $650 \mathrm{~m}$ to $1,950 \mathrm{~m}$ above sea level. The lower catchments are covered with meadows and forest, while no soil cover is present in the higher regions.

The flysch rocks consist of clastic turbidite sediments deposited in deep marine environments. These sediments contain detrital components of various alpine rock types, such as carbonate rocks, shale, sandstone, schist, gneiss, quartzite, amphibolite, and various igneous rocks. Conglomerates and sandstones are partly cemented with carbonate minerals or contain a clay matrix. The abundant intercalated shale and fine-grained siltstone beds limit regional groundwater circulation, and catchments are commonly small, with $80 \%$ covering an area of less than about $1 \mathrm{~km}^{2}$. The alpine tectonic overprint resulted in intense fracturing, internal folding, and over-thrusting of the flysch rocks, giving rise to open fracture networks and rapid groundwater flow. In local limestone bands, microkarst features have developed. Seasonal variations in discharge of recent flysch groundwaters are usually high, while the variations in temperature and mineralisation are limited. Tracer tests revealed groundwater residence times in the order of days to months (Basabe 1993).

\section{Hydrochemistry of Recent Groundwaters}

The chemical composition of recent groundwater is characteristic for each aquifer type, i.e. the aquifer lithology in which the groundwaters evolve. While there exists a certain overlap in major element composition due to the limited variability of kinetically fast reacting minerals, as shown in Figs. 2 and 3, Fig. 4 and Table 3 illustrate that the trace element concentrations reveal clear trends for the different aquifer types. Common features of all sampled groundwaters are their low water temperatures (between $0.2^{\circ}$ and $18.3^{\circ} \mathrm{C}$ ), the occurrence of abundant dissolved oxygen, and $\mathrm{pH}$ values between 5.9 and 8.5 (Table 3).

\section{Crystalline-Rock Aquifers}

Groundwaters from the crystalline rocks (granite and gneiss; Fig. 1) of the Mont-Blanc and Aiguilles-Rouges Massifs (Switzerland and France) are very dilute [22 to $158 \mathrm{mg} / \mathrm{L}$ total dissolved solids (TDS), Table 3] and generally of the $\mathrm{Ca}-\mathrm{HCO}_{3}-\mathrm{SO}_{4}$ type. In certain cases, $\mathrm{Na}^{+}, \mathrm{Mg}^{2+}$, and $\mathrm{F}^{-}$occur as additional major cations and anions, respectively. Groundwaters evolving in gneiss and granite aquifers have different chemical compositions. Gneiss groundwaters tend to have a higher total mineralisation and $\mathrm{pH}$ value than granite groundwaters due to higher concentrations of $\mathrm{Mg}^{2+}, \mathrm{Ca}^{2+}, \mathrm{Sr}^{2+}$ and associated higher alkalinity in gneiss groundwaters (Table 3 ). In contrast, granite groundwaters typically contain higher concentrations of $\mathrm{Na}^{+}, \mathrm{K}^{+}$, and $\mathrm{F}^{-}$. In both types, a positive trend between water temperature and dissolved silica concentration is developed (Fig. 5). Despite their low total mineralisation, granite- and gneiss-derived groundwaters have high concentrations of characteristic trace elements. For the granite groundwaters these are Mo, U, W, and As 

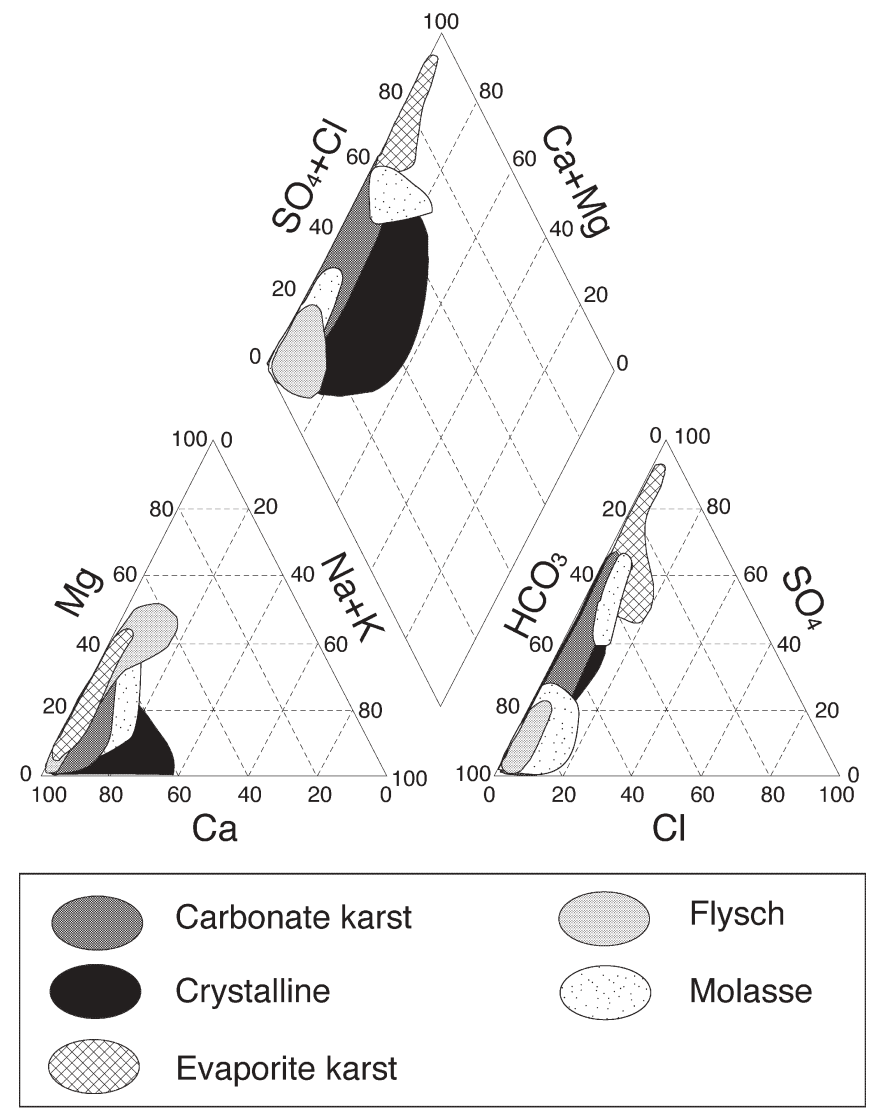

Fig. 2 Piper diagram (Piper 1953) depicting the distribution of major element compositions in groundwaters from the different aquifer types (milliequivalents normalised to $100 \%$ )

(Table 3, Fig. 4). Gneiss groundwaters generally contain higher $\mathrm{Ba}$ and As concentrations than groundwaters from granite.

Within the analytical uncertainty, groundwaters from the granite and gneiss aquifers are undersaturated with respect to calcite, dolomite, gypsum, fluorite, celestite, strontianite, barite and all slowly reacting Al-silicate minerals (Table 4). Only equilibrium with respect to chalcedony is approached, indicating that dissolved silica is subjected to solubility control by a pure $\mathrm{SiO}_{2}$ mineral phase. In the granite groundwaters, an evolutionary trend towards solubility control of $\mathrm{F}^{-}$by fluorite is observed and, in a few samples, fluorite equilibrium is almost reached. The gneiss groundwaters, in contrast, tend to be closer to saturation with respect to calcite, dolomite, gypsum, celestite, strontianite and barite than the granite groundwaters, due to their higher activities of $\mathrm{CO}_{3}{ }^{2-}$ (related to the higher $\mathrm{pH}$ ), $\mathrm{Ca}^{2+}, \mathrm{Mg}^{2+}, \mathrm{Sr}^{2+}$, and $\mathrm{Ba}^{2+}$ (Table 4). Calculated $\mathrm{P}_{\mathrm{CO} 2}$ values range from $10^{-1.5}$ bar to $10^{-3.9}$ bar with a median of $10^{-2.6}$ bar. At comparable total inorganic carbon (TIC) contents, granite groundwaters tend to have higher $\mathrm{P}_{\mathrm{CO} 2}$ values than the gneiss groundwaters due to their lower $\mathrm{pH}$ value.

\section{Carbonate-Rock Aquifers}

Carbonate karst groundwaters are characterised by a total mineralisation between 161 to $547 \mathrm{mg} / \mathrm{L}$ TDS (Table 3). Groundwaters that discharge at low altitude springs are more highly mineralised than those at high altitude springs. Depending on aquifer lithology, three major hydrochemical facies can be discerned. Groundwaters from pure limestone aquifers are dominantly of the $\mathrm{Ca}-\mathrm{HCO}_{3}$ type. Groundwaters from dolomitic limestone or dolostone aquifers are of the $\mathrm{Ca}-\mathrm{Mg}-\mathrm{HCO}_{3}$ type, while those from aquifers composed of carbonate series containing evaporite beds are of the $\mathrm{Ca}-\mathrm{Mg}-\mathrm{HCO}_{3}-\mathrm{SO}_{4}$ type. The contents of $\mathrm{Na}^{+}$and $\mathrm{Cl}^{-}$are generally low with the exception of springs close to the coast in Slovenia and Greece, where the groundwater chemistry is influenced by sea spray. The $\mathrm{Na}^{+} / \mathrm{Cl}^{-}$ratio remains constant over the entire concentration range and is similar to that of rain and seawater, respectively. There is a positive correlation between dissolved silica concentration and water temperature (Fig. 5). In dolomitic limestone and dolostone aquifers, $\mathrm{Sr}$ shows a positive trend with $\mathrm{Ca}$, while in carbonate rocks with evaporite beds $\mathrm{Sr}$ is positively cor-

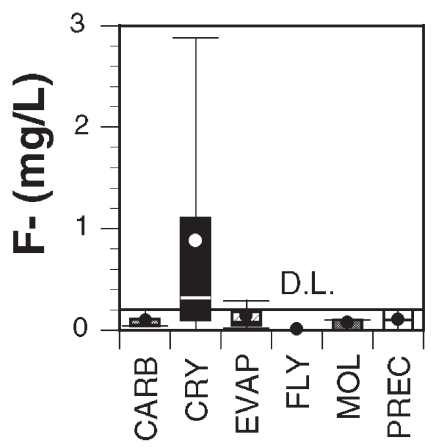

Fig. 3 Box plots showing natural $\mathrm{F}^{-}, \mathrm{Sr}^{2+}$, and $\mathrm{Si}$ concentration ranges in groundwaters from the different aquifer types and in precipitation $(\mathrm{CARB}=$ groundwaters from carbonate rocks; $\mathrm{CRY}=$ groundwaters from crystalline rocks, EVAP=groundwaters from evaporite rocks, FLY=groundwaters from flysch rocks, $\mathrm{MOL}=$ groundwaters from molasse rocks, $\mathrm{PREC}=$ precipitation water). The boxes show the inter quartile range $\left(25^{\text {th }}\right.$ percentile to $75^{\text {th }}$
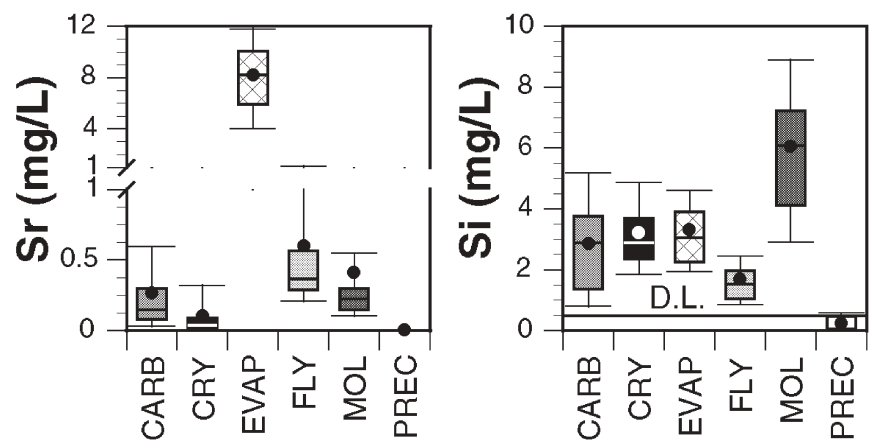

percentile) and median values (the line through the middle of the box). The "whiskers" above and below the boxes extend from the $10^{\text {th }}$ percentile to the $90^{\text {th }}$ percentile and the black point displays the arithmetic mean. Outliers (lower than $10^{\text {th }}$ percentile or higher than the $90^{\text {th }}$ percentile) are not plotted. D.L.=detection limit, values below are qualitative 
Fig. 4 Box plots showing natural concentration ranges of selected trace elements in groundwaters from the different aquifer types and in precipitation. See Fig. 3 for abbreviations and Table 3 for complete concentration ranges
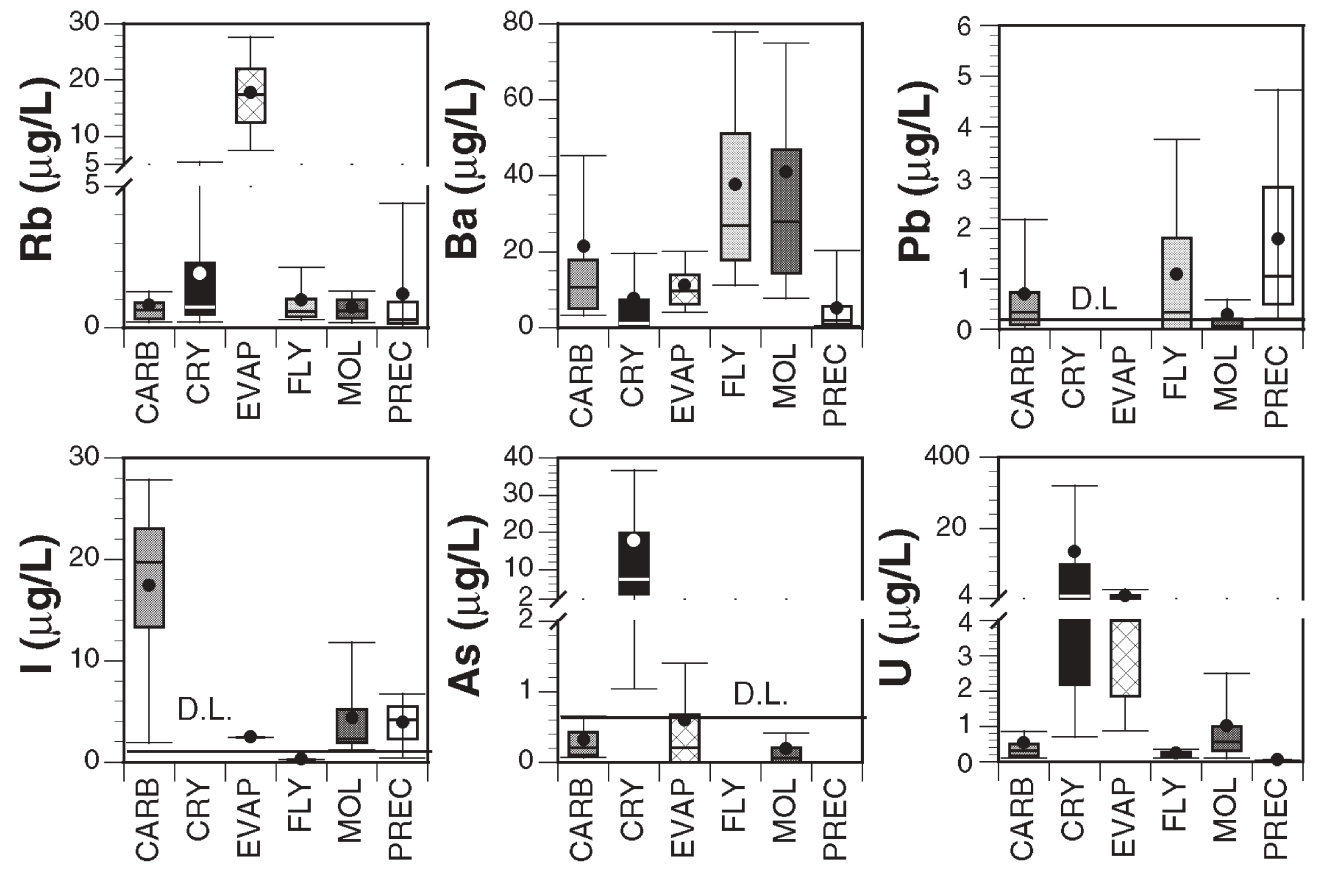

related with $\mathrm{SO}_{4}$. Trace element concentrations in carbonate karst groundwaters are generally very low, but some of them appear to represent natural tracers: Iodine is often present at elevated concentrations in carbonate karst groundwaters, independent of the sedimentary environment of the aquifer (Table 3, Fig. 4). Groundwaters evolving in deep-sea limestone are commonly enriched with Ba (Apennine, NW Greece, and Malm of the Préalpes). Vanadium is enriched in groundwaters from the Malm limestone of the Swiss Jura Mountains and from the Trieste region. Mo and $U$ are often enriched in groundwaters from dolomite-bearing aquifers.

Calcite equilibrium is only attained in the warmer, more mineralised karst groundwaters that discharge at low altitude springs, while the cold waters from mountain springs are undersaturated with respect to calcite (Table 4). Calculated $\mathrm{P}_{\mathrm{CO} 2}$ values are distinctly higher than that of the atmosphere and range from $10^{-1.1}$ to $10^{-2.8} \mathrm{bar}$. Most of the carbonate karst groundwaters are undersaturated with respect to dolomite, and all of them are undersaturated with respect to gypsum, fluorite, strontianite, and celestite. Saturation with chalcedony is only reached in some of the warmer and more mineralised karst groundwaters.

\section{Evaporite-Rock Aquifers}

Evaporite groundwaters have the highest mineralisation of all investigated groundwaters (760 to $2,788 \mathrm{mg} / \mathrm{L}$ TDS, Table 3) and show only small compositional variation. They are typically of the $\mathrm{Ca}-\mathrm{Mg}-\mathrm{SO}_{4}-\mathrm{HCO}_{3}$ chemical type with $\mathrm{Ca}^{2+}, \mathrm{Mg}^{2+}$, and $\mathrm{SO}_{4}{ }^{2-}$ making up 80 to $90 \%$ of the total mineralisation. Strontium is usually present at higher concentrations than $\mathrm{Na}^{+}, \mathrm{K}^{+}, \mathrm{F}^{-}$and $\mathrm{Cl}^{-}$and shows a positive correlation with $\mathrm{SO}_{4}{ }^{2-}$. Characteristic trace el- ements in evaporite-derived groundwaters include $\mathrm{Li}, \mathrm{Rb}$, $\mathrm{Ni}, \mathrm{Cu}, \mathrm{Cd}$, and $\mathrm{Mn}$ (Table 3, Fig. 4). All of these trace elements have also been detected in the leachate solutions of gypsum and/or anhydrite-bearing evaporites, confirming their natural origin (Mandia 1993). Elevated U contents occur in the evaporite groundwaters of the Helvetic and Penninic tectonic units.

Most of the recent evaporite-derived groundwaters are close to or in equilibrium with calcite, dolomite, gypsum, barite, and chalcedony, and they are undersaturated with respect to fluorite (Table 4). In some groundwaters, equilibrium is attained with celestite, while strontianite is undersaturated in all groundwaters, due to the high $\mathrm{Sr}^{2+}$ and $\mathrm{SO}_{4}{ }^{2-}$, but low $\mathrm{CO}_{3}{ }^{2-}$ activities. It appears that the concentrations of dissolved $\mathrm{Ca}^{2+}, \mathrm{Mg}^{2+}, \mathrm{SO}_{4}{ }^{2-}, \mathrm{Sr}^{2+}$, $\mathrm{CO}_{3}{ }^{-2}$, and silica are limited by the mineral solubility of calcite, gypsum, dolomite, chalcedony, and celestite.

\section{Molasse-Rock Aquifers}

The majority of recent groundwaters evolving in molasse aquifers is of the $\mathrm{Ca}-\mathrm{Mg}-\mathrm{HCO}_{3}$ type with strongly variable total mineralisations between about $48 \mathrm{mg} / \mathrm{L}$ and $714 \mathrm{mg} / \mathrm{L}$ and pronounced concentrations of dissolved silica (Table 3, Fig. 2). Several molasse formations have specific mineralogical compositions that result in distinct groundwater compositions (Hesske 1995, Hesske et al. 1997). Groundwaters of the $\mathrm{Ca}-(\mathrm{Mg})-\mathrm{SO}_{4}-\mathrm{HCO}_{3}$ chemical type, a total mineralisation that exceeds $1,000 \mathrm{mg} / \mathrm{L}$, and elevated contents of $\mathrm{Sr}, \mathrm{Li}, \mathrm{Mo}, \mathrm{U}, \mathrm{Br}$, and $\mathrm{B}$ (Table 3) are observed in the "Gypsum-bearing molasse" (Lower Freshwater Molasse). This formation occurs along the Jura Mountains in western Switzerland and consists of gypsum-bearing sandstones and marls with intercalated dolomitic limestone layers. Elevated $\mathrm{SO}_{4}{ }^{2-}$ contents are 


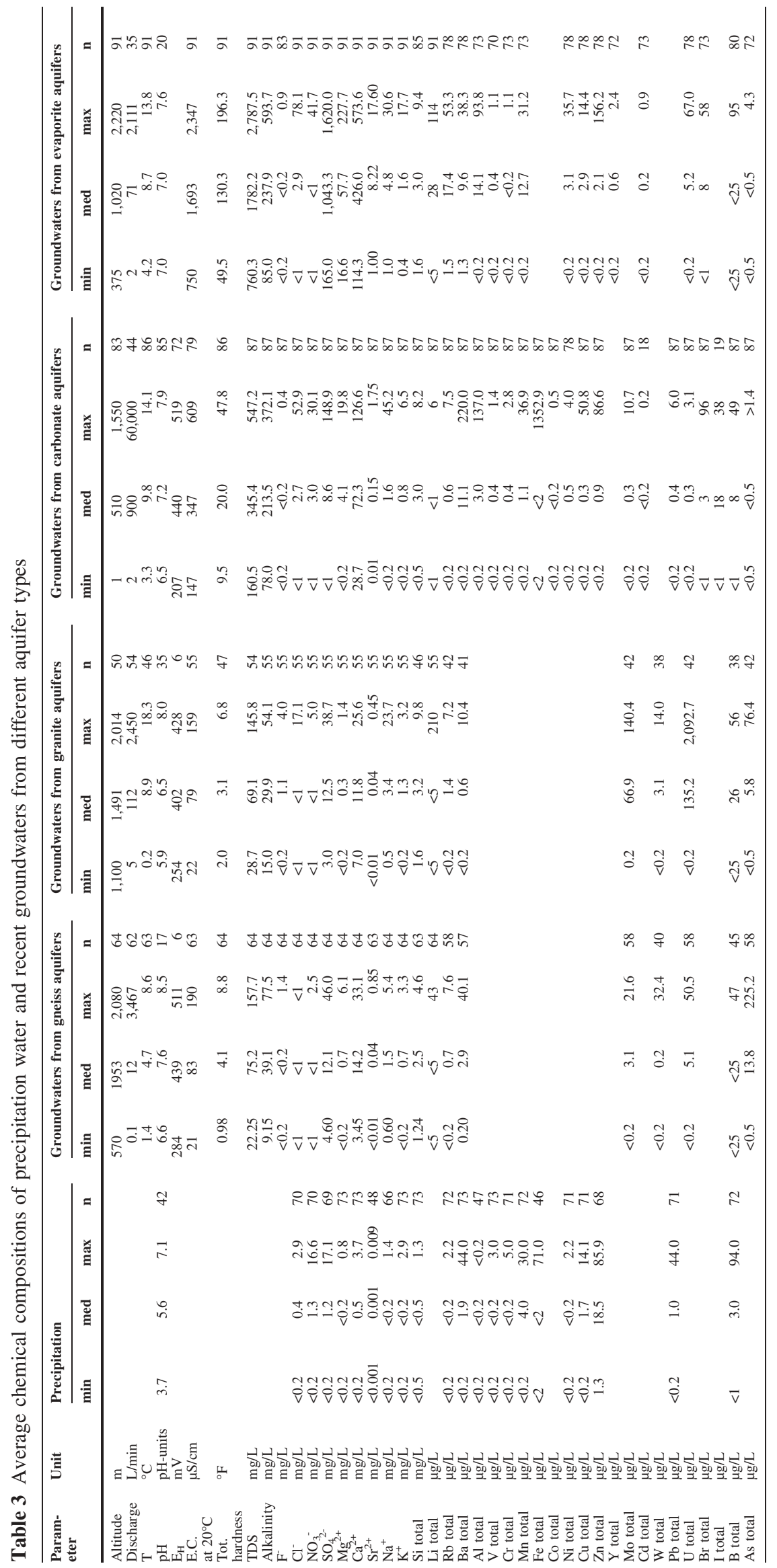




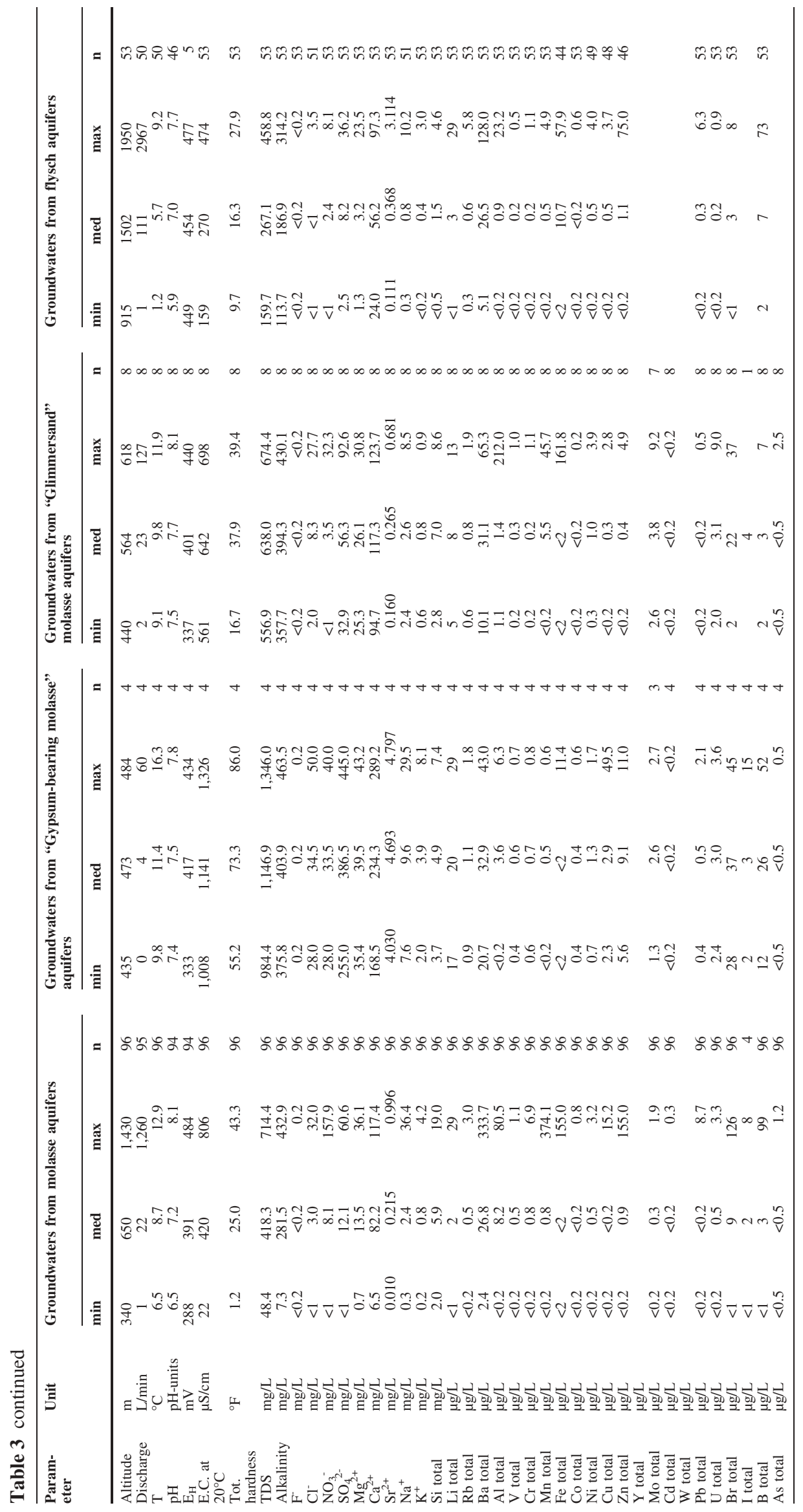




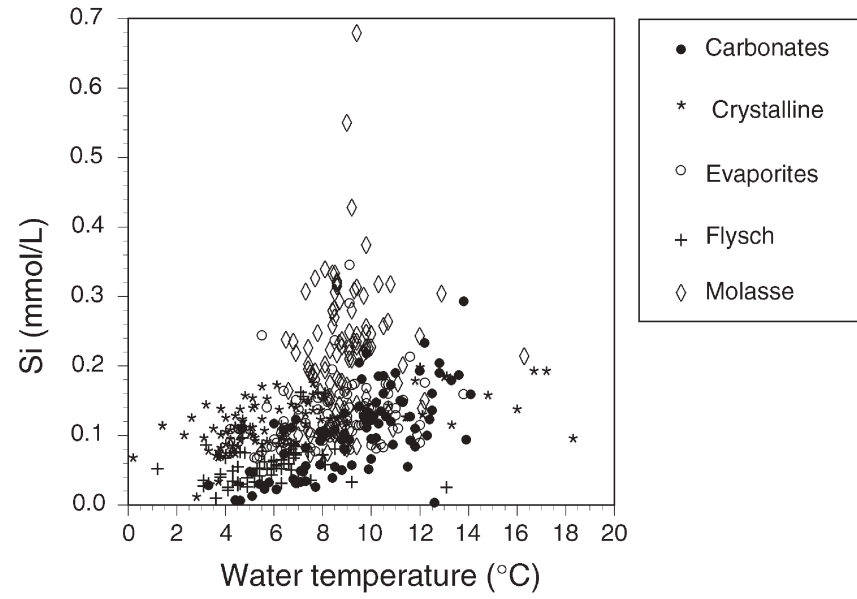

Fig. 5 Si concentrations compared to groundwater temperature in the different aquifer types

also recorded for groundwaters evolving in the "Glimmersand Formation" (Upper Freshwater Molasse) that occurs along the Jura Mountains in northeastern Switzerland and in the Schwäbische and Fränkische Alb region (southeastern Germany). This formation consists of granite detritus and is developed as well-sorted, poorlycemented mica-rich calcareous sandstones. Here, the elevated $\mathrm{SO}_{4}{ }^{2-}$ contents are related to sulphide mineral oxidation and characteristic trace elements include Mo, $\mathrm{U}$, and $\mathrm{Li}$ (Table 3). Groundwater from the glauconitebearing sandstones of the Upper Marine Molasse in western Switzerland is characterised by naturally elevated $\mathrm{Cr}$ concentrations (1.9 to $6.9 \mu \mathrm{g} / \mathrm{L}$ ). Dissolved $\mathrm{Ba}$ in concentrations between 50 and $334 \mu \mathrm{g} / \mathrm{L}$ is a natural tracer for groundwater that evolved in the conglomerate sediments of the Lower Freshwater and Upper Marine Molasse in certain regions of western and central Switzerland (Gibloux fan, Rigi-Rossberg fan, and Grès de la Cornalle).

Most of the investigated molasse groundwaters are in equilibrium with calcite and chalcedony and are at or close to equilibrium with dolomite and barite (Table 4), which is consistent with the relatively long average residence time. Calculated $\mathrm{P}_{\mathrm{CO} 2}$ values ranging from $10^{-1.3}$ to $10^{-3.0}$ bar indicate that the uptake of soil $\mathrm{CO}_{2}$ plays an important role in the mineralisation of molasse groundwaters. Molasse groundwaters are generally undersaturated with respect to gypsum, celestite, strontianite and fluorite. Similar to the evaporite groundwaters, groundwaters from the "Gypsum-bearing molasse" are close to saturation with respect to gypsum and celestite.

\section{Flysch-Rock Aquifers}

Most of the flysch groundwaters are of the $\mathrm{Ca}-\mathrm{HCO}_{3}$ or $\mathrm{Ca}-$ $(\mathrm{Mg})-\mathrm{HCO}_{3}$ chemical type with total mineralisations between $160 \mathrm{mg} / \mathrm{L}$ and $459 \mathrm{mg} / \mathrm{L}$ (Table 3). Flysch spring waters generally show low concentrations of dissolved $\mathrm{Na}^{+}$, $\mathrm{K}^{+}, \mathrm{Cl}^{-}, \mathrm{SO}_{4}{ }^{2-}, \mathrm{Sr}^{2+}$, and silica. Typically, they have very low trace element concentrations, with the exception of Ba.
As a consequence of the commonly very short residence time of flysch groundwaters, only a few of them have reached equilibrium with calcite, while the majority of these waters are undersaturated with respect to all investigated mineral phases (Table 4). Dissolved $\mathrm{CO}_{2}$ in the flysch groundwaters is mainly soil derived, and $\mathrm{P}_{\mathrm{CO} 2}$ values vary between $10^{-0.9}$ and $10^{-2.8}$ bar.

\section{Geochemical Evolution of Recent Groundwaters}

The geochemical evolution of recent groundwater is determined by the abundance of minerals with fast reaction kinetics and by their accessibility to water. While the abundance of such minerals is the result of the geological history of the aquifer rock, their probability to dissolve depends on the groundwater flow characteristics of the aquifer. The chemical typology combined with the total mineralisation of the 1,475 recent groundwaters from different aquifer types indicates that the carbonate and the sulphate/sulphide systems play dominant roles in the evolution of such groundwaters. Depending on aquifer mineralogy and type of groundwater flow, however, groundwater mineralisation results from different processes, which are of special importance to the minor and trace element mineralisation. Fast reacting carbonate, sulphate and/or sulphide minerals are present in all aquifer rock types. The dissolution of calcite, and in some cases dolomite, gypsum, anhydrite and/or pyrite (and other less abundant metal sulphides) therefore largely determine the major element composition of these groundwaters.

Most recent groundwaters from crystalline, carbonate karst, molasse, and flysch aquifers have molar $\mathrm{HCO}_{3} / \mathrm{Ca}$ ratios of 2:1, as illustrated in Fig. 6. Within the $\mathrm{pH}$ range observed for these groundwaters, this is characteristic of calcite dissolution promoted by $\mathrm{CO}_{2}$ uptake, according to

$$
\mathrm{CaCO}_{3(\mathrm{~s})}+\mathrm{H}_{2} \mathrm{O}+\mathrm{CO}_{2} \Leftrightarrow \mathrm{Ca}^{2+}+2 \mathrm{HCO}_{3}^{-}
$$

The $\mathrm{CO}_{2}$ in this reaction is derived from the atmosphere and, where present, from the soil cover. Deviations from this general trend are mainly due to additional sources or sinks of $\mathrm{Ca}$ (see below). In aquifer rocks that contain sulphate minerals, $\mathrm{Ca}$ and $\mathrm{SO}_{4}$ are mainly derived from the dissolution of gypsum (reaction 2) and/or anhydrite (reaction 3 ) as exemplified by the observed molar $\mathrm{Ca} / \mathrm{SO}_{4}$ ratio of close to $1: 1$ in recent groundwaters from evaporite aquifers (Fig. 7) :

$$
\begin{aligned}
& \mathrm{CaSO}_{4} \cdot 2 \mathrm{H}_{2} \mathrm{O}_{(\mathrm{s})} \Leftrightarrow \mathrm{Ca}^{2+}+\mathrm{SO}_{4}^{2-}+2 \mathrm{H}_{2} \mathrm{O} \\
& \mathrm{CaSO}_{4(\mathrm{~s})} \Leftrightarrow \mathrm{Ca}^{2+}+\mathrm{SO}_{4}^{2-}
\end{aligned}
$$

In aquifer rocks that contain no sulphate but sulphide minerals, dissolved $\mathrm{SO}_{4}$ is derived in oxygenated recent groundwaters by sulphide (mainly pyrite) oxidation, according to

$$
\mathrm{FeS}_{2}+15 / 4 \mathrm{O}_{2}+7 / 2 \mathrm{H}_{2} \mathrm{O} \Leftrightarrow \mathrm{Fe}^{\mathrm{III}}(\mathrm{OH})_{3(\mathrm{~s})}+2 \mathrm{SO}_{4}^{2-}+4 \mathrm{H}^{+}
$$




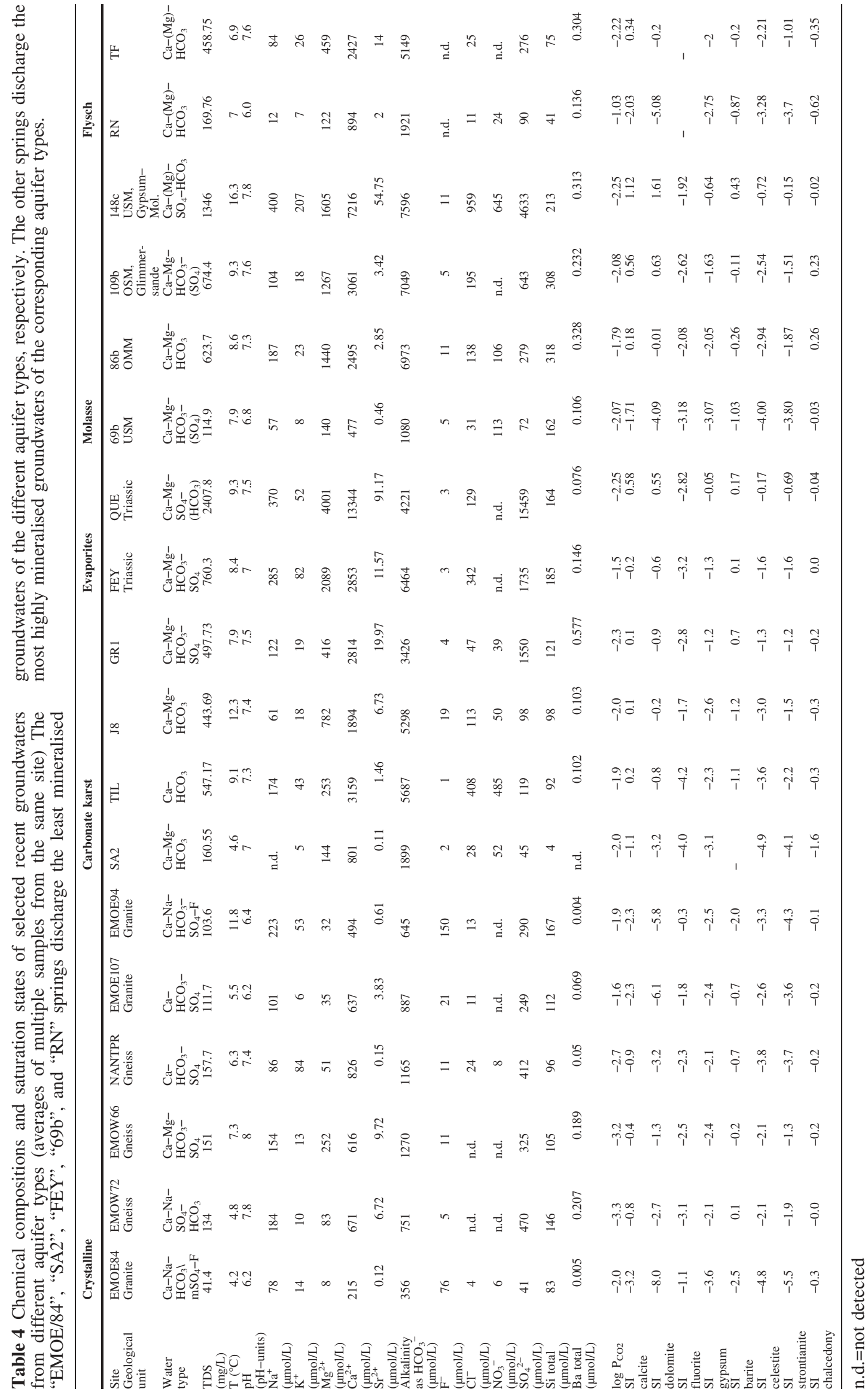




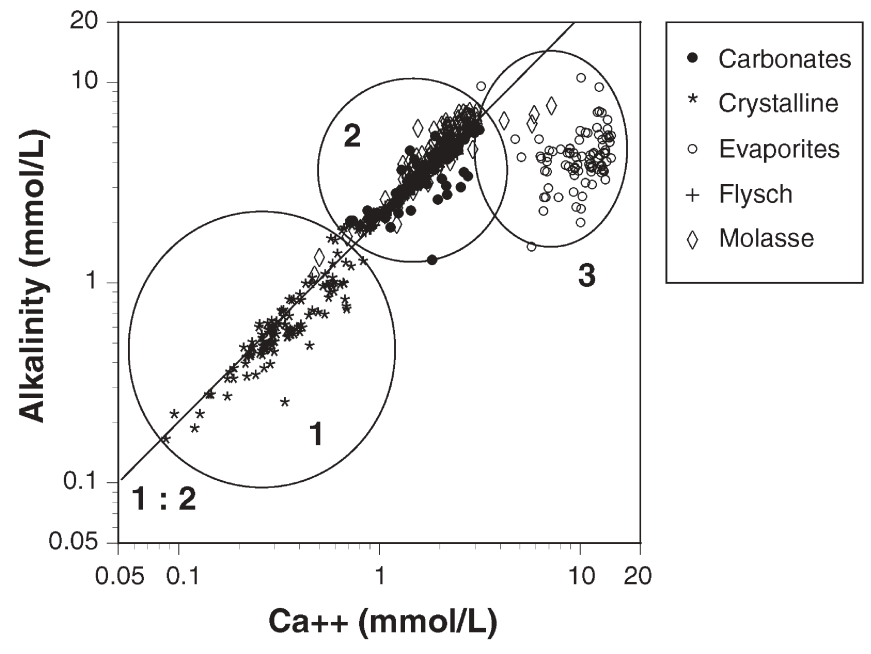

Fig. 6 Molar $\mathrm{Ca}^{2+}$ concentrations compared to alkalinity in groundwaters from the different aquifer types. Three groups can be distinguished: 1: groundwaters from crystalline rocks, 2: groundwaters from carbonate rocks and from calcareous clastic sediments (molasse and flysch) and 3: groundwaters from evaporite rocks. See text for an explanation of the $1: 2$ ratio

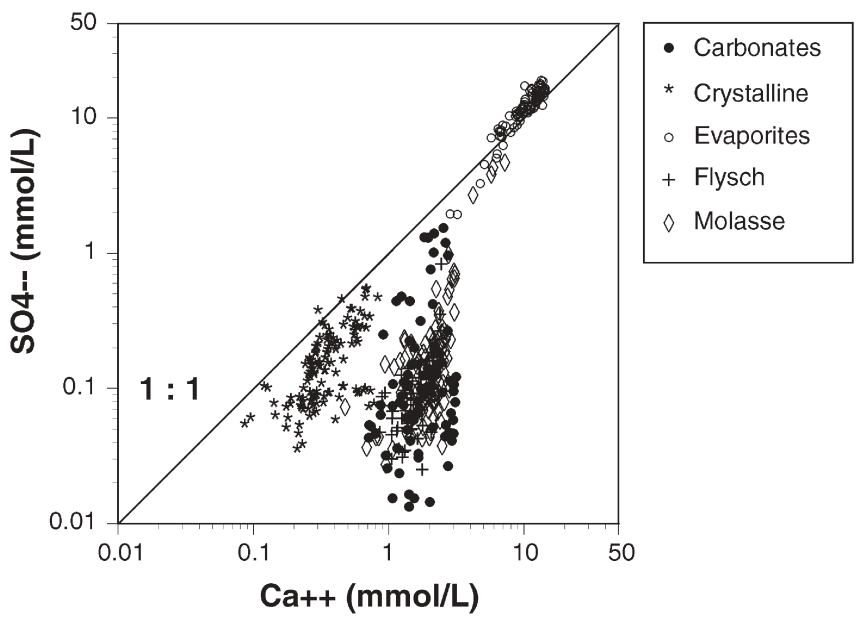

Fig. 7 Molar $\mathrm{Ca}^{2+}$ concentrations compared to $\mathrm{SO}_{4}{ }^{2-}$ in groundwaters from the different aquifer types. See text for an explanation of the $1: 1$ ratio

In this case, there is no correlation between major cations and dissolved $\mathrm{SO}_{4}$, as is shown, for example, by the crystalline recent groundwaters (Fig. 7). Because the investigated groundwaters have an oxidising redox potential, the $\mathrm{Fe}^{\mathrm{II}}$ released during pyrite oxidation is oxidised and precipitates as Fe-hydroxides. Other trace metals may be released during sulphide oxidation, but are not necessarily subjected to rigorous solubility control by a hydroxide mineral phase as in the case of iron. Consequently, sulphide oxidation is an important process for the mobilisation of aquifer lithology-specific trace elements in recent groundwaters.
Reactions (1) to (4) describe the most important processes for the mineralisation of recent groundwaters from different aquifer types. Further processes are aquifer typespecific. The comparison of major element composition and total mineralisation of the investigated groundwaters shows that the overall geochemical evolution is similar for waters from carbonate rocks (carbonate karst) and carbonaceous clastic sediments (molasse and flysch), but different for evaporite and crystalline aquifer environments (Fig. 6).

Recent Groundwaters from Crystalline Catchments In crystalline aquifers, recent groundwaters with a residence time of up to two years circulate predominantly along tectonic discontinuities (fracture flow) and the minerals present along fracture and fissure planes control their hydrochemistry. The fracture mineral assemblage is mainly of hydrothermal origin and differs substantially from the bulk rock composition. It generally includes more reactive minerals, such as sulphides, carbonates, and fluorite, compared to the kinetically sluggish Al-silicates of the rock matrix.

The general evolution of the granite and gneiss groundwaters can be explained by the dissolution of calcite, fluorite, a pure silica phase, sulphides (pyrite), and by $\mathrm{Na}-\mathrm{Ca}$ ion exchange on clay minerals as a source of $\mathrm{Na}^{+}$. Mass balance calculations show that mass transfer along the flow paths from infiltrating rainwater to groundwater discharge is small, in the order of a few tenths of a millimole per litre of solution (Table 5). The calculations suggest that dissolved $\mathrm{Ca}^{2+}$ is mainly derived by the dissolution of small amounts of hydrothermal carbonate minerals and not from weathering of Ca-bearing $\mathrm{Al}$-silicate minerals such as plagioclase, which is in agreement with other weathering studies in crystalline environments (White et al. 1999; Blum et al. 1998; Harris et al. 1998). In catchments with a soil cover, calcite dissolution is promoted by soil $\mathrm{CO}_{2}$ according to reaction (1). Calcite dissolution in the crystalline-rock groundwaters is further promoted by the acidity produced during pyrite oxidation, according to

$\mathrm{CaCO}_{3}+\mathrm{H}^{+} \Leftrightarrow \mathrm{Ca}^{2+}+\mathrm{HCO}_{3}^{-}$

A comparison of reactions (4) and (5) shows that four moles of calcite are needed per mol pyrite dissolved to buffer the acidity (note that the crystalline-rock groundwaters have $\mathrm{pH}$ values between 6 and 8 ). As the molar $\mathrm{HCO}_{3} / \mathrm{Ca}$ ratio is $1: 1$ in reaction (5), this will result in a lower molar $\mathrm{HCO}_{3} / \mathrm{Ca}$ ratio compared to calcite dissolution promoted by $\mathrm{CO}_{2}$. As shown in Fig. 6, this is observed for many of the crystalline-rock groundwaters. Calcite dissolution caused by pyrite oxidation has also been proposed by Lebdioui et al. (1990) based on stable isotope signatures $\left({ }^{34} \mathrm{~S},{ }^{18} \mathrm{O}\right.$ and $\left.{ }^{13} \mathrm{C}\right)$ in groundwaters from the Mont-Blanc road tunnel.

A similar shift of the $\mathrm{HCO}_{3} / \mathrm{Ca}$ ratio of 2:1 towards lower values is induced by the dissolution of fluorite 


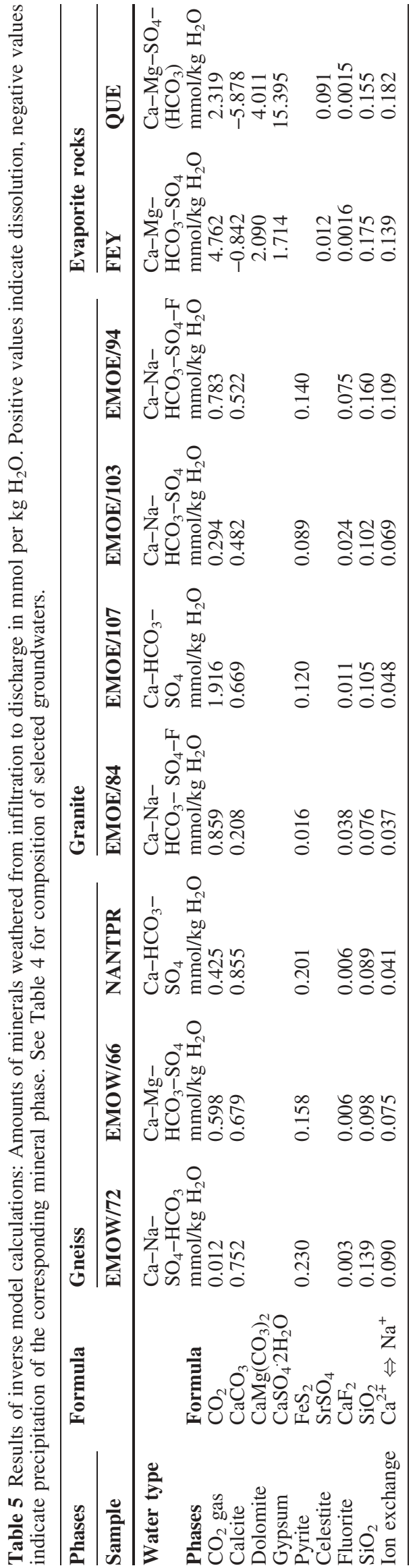

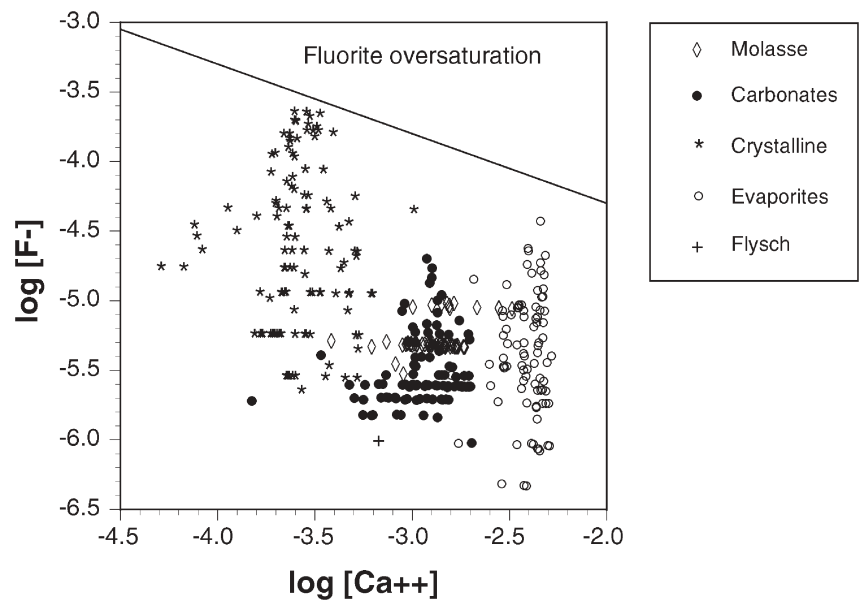

Fig. 8 Comparison of the fluorite solubility in $\mathrm{Ca}^{2+}$-poor groundwaters from crystalline rocks and in $\mathrm{Ca}^{2+}$-rich groundwaters from evaporite rocks (values plotted are activities)

(reaction 6). This shift, however, is much smaller due to the smaller amount of fluorite dissolution required (Table 5).

$\mathrm{CaF}_{2} \Leftrightarrow \mathrm{Ca}^{2+}+2 \mathrm{~F}^{-}$

Fluorite is a typical hydrothermal mineral in the MontBlanc granite and because of its fast dissolution kinetics it is likely to be the major source of dissolved $\mathrm{F}^{-}$. The concentration of dissolved $\mathrm{F}^{-}$is limited only by the solubility of fluorite, as illustrated in Fig. 8. Because $\mathrm{Ca}^{2+}$ activities are low in the crystalline-rock groundwaters, solubility control by fluorite only sets an upper limit to high $\mathrm{F}^{-}$activities corresponding to $\mathrm{F}^{-}$concentrations of approximately $4.8 \mathrm{mg} / \mathrm{L}$. In comparison, saturation with fluorite in evaporite aquifers is attained at significantly lower $\mathrm{F}^{-}$concentrations (around $1.1 \mathrm{mg} / \mathrm{L}$ ). Natural background concentrations of $\mathrm{F}^{-}$in crystalline-rock (especially granite) groundwaters might therefore surpass World Health Organisation (WHO) drinking water recommendations $(1.5 \mathrm{mg} / \mathrm{L}$, WHO 1993, 1998).

Readily dissolvable Na-bearing minerals occur neither in the granite nor in the gneiss. Therefore, the most likely source of dissolved $\mathrm{Na}^{+}$in the crystalline-rock aquifers is $\mathrm{Ca}-\mathrm{Na}$ ion exchange on clay minerals, which liberates 2 moles of $\mathrm{Na}^{+}$per mole of adsorbed $\mathrm{Ca}^{2+}$ :

$2 \mathrm{Na}-\mathrm{X}+\mathrm{Ca}^{2+} \Leftrightarrow 2 \mathrm{Na}^{+}+\mathrm{Ca}-\mathrm{X}$

Clay minerals that can serve as exchangers (X), occur as abundant fracture linings in the crystalline rocks. In addition, ion exchange reactions proceed quickly compared to mineral dissolution or precipitation reactions, and equilibrium is almost always established (Appelo and Postma 1996).

The distinct occurrence of natural trace elements such as $\mathrm{U}, \mathrm{Mo}, \mathrm{As}, \mathrm{W}$, and $\mathrm{Ba}$ in crystalline-rock groundwaters might be used as evidence for hydraulic conditions dominated by fracture flow: These trace elements occur in the abundant hydrothermal fracture linings in the Mont- 
Blanc and Aiguilles-Rouges Massifs, but not (or only very subordinately) in the rock matrix. The natural trace element concentrations observed in the groundwaters are derived from (partial) dissolution of hydrothermal fracture mineral phases such as molybdenite $\left(\mathrm{MoS}_{2}\right)$, various U-minerals, scheelite $\left(\mathrm{CaWO}_{4}\right)$, arsenopyrite (FeAsS), and barite $\left(\mathrm{BaSO}_{4}\right)$. Aqueous speciation calculations revealed that under the prevailing $\mathrm{pH}$ and redox (oxidising) conditions, $\mathrm{U}, \mathrm{As}, \mathrm{Mo}$ and $\mathrm{W}$ in solution will be present in anionic forms such as $\mathrm{U}^{\mathrm{VI}}$-carbonate complexes, and $\mathrm{As}^{\mathrm{V}-}{ }_{-}, \mathrm{Mo}^{\mathrm{V}}, \mathrm{VI}_{-}$, and $\mathrm{W}^{\mathrm{VI}}$-oxy-anions, respectively. Under present conditions, there is no mineral solubility control for these trace metals, and therefore dissolved concentrations can be limited only via sorption, e.g. on secondary Fe-hydroxides.

\section{Recent Groundwaters from Carbonate and Calcareous Clastic-Sediment Catchments}

Groundwater flow in conduits is rapid, sometimes even turbulent, leading to very short residence times of karst groundwaters. In contrast, diffuse flow through fissures and pores in clastic sediments (molasse and flysch) is much slower, and results in residence times of water of up to a few years. The hydrochemical evolution of the groundwaters from carbonate sediments and calcareous molasse and flysch rocks is dominated by calcite dissolution. Calcite dissolution in these soil-covered catchments is enhanced by the uptake of soil $\mathrm{CO}_{2}$ (reaction 1), as indicated by molar $\mathrm{HCO}_{3} / \mathrm{Ca}$ ratios of around $2: 1$ (Fig. 6). Some of the carbonate karst, molasse, and flysch groundwaters are still undersaturated with respect to calcite. This can be related to the complex calcite dissolution kinetics which depend on factors such as flow velocity, residence time, and temperature of the groundwater (Appelo and Postma 1996; Dreybrodt 1998).

In some carbonate karst, molasse, and flysch aquifers, dolomite constitutes an important mineral phase. Given a long enough residence time, dolomite dissolution promoted by soil $\mathrm{CO}_{2}$ becomes important:

$$
\mathrm{CaMg}\left(\mathrm{CO}_{3}\right)_{2(\mathrm{~s})}+2 \mathrm{H}_{2} \mathrm{O}+2 \mathrm{CO}_{2} \Leftrightarrow \mathrm{Ca}^{2+}+\mathrm{Mg}^{2+}+4 \mathrm{HCO}_{3}^{-}
$$

Dolomite dissolution is responsible for the higher concentrations of $\mathrm{HCO}_{3}{ }^{-}$and $\mathrm{Mg}^{2+}$ in the molasse groundwaters and in some more evolved carbonate karst and flysch groundwaters, and for the observed shift in the $\mathrm{HCO}_{3} / \mathrm{Ca}$ ratio towards values greater than 2:1 (Fig. 6). In the special case of the "Gypsum-bearing molasse" and certain carbonate karst aquifers containing evaporite beds, the dissolution of gypsum (reaction 2) causes a shift in the $\mathrm{HCO}_{3} / \mathrm{Ca}$ ratio in the opposite direction, towards higher $\mathrm{Ca}^{2+}$ concentrations.

Carbonate karst groundwaters generally contain very low trace element contents due to their very short residence times and because calcite contains only very restricted amounts of trace elements. Organic matter (including fossil organic substances) and a few accessory minerals are the most important sources for the observed trace element contents in carbonate karst groundwaters. Observations from recent marine carbonate sediment environments show that $\mathrm{I}^{-}$is normally associated with organic material and is released into solution during decomposition of this material under oxidising conditions (Martin et al 1993). The observed elevated $\mathrm{I}^{-}$contents in carbonate karst groundwaters can therefore be attributed to the decomposition of fossil organic matter. In groundwaters from deep sea limestone, the characteristically elevated $\mathrm{Ba}$ contents can be connected to the dissolution of dispersed micro-crystalline barite, which occurs in these rocks in quantities up to $10 \mathrm{wt} \%$ (Church 1979). Uranium and molybdenum can be present at elevated concentrations in groundwaters from certain dolomite-bearing aquifers containing minor sulphide mineralisations including $\mathrm{U}$ and Mo, which are dissolved by the oxygenated groundwaters. Small amounts of $U$ and Mo can also be incorporated into dolomite and are released during its dissolution (Wedepohl 1978). Groundwaters from carbonate karst aquifers containing evaporite layers are characterised by elevated $\mathrm{Sr}^{2+}$ and $\mathrm{Li}^{+}$concentrations due to the dissolution of gypsum and celestite (Holser 1979a, 1979b). Malm limestones in the western Swiss Jura (particularly the Portlandian Formation (Malm); Dematteis 1995) and the bituminous Cretaceous limestones near Trieste have elevated V concentrations as do their associated recent groundwaters. In these catchments, $\mathrm{V}$ is released from the rock during oxidation of organic material and is present in the groundwater as highly mobile anionic complexes such as $\mathrm{H}_{2} \mathrm{VO}_{4}{ }^{-}$and $\mathrm{HVO}_{4}{ }^{2-}$.

The particular mineralogy of certain molasse formations is reflected in specific natural trace element compositions of associated groundwaters. Elevated $\mathrm{Cr}$ concentrations are recorded for the Upper Marine Molasse sandstones in western Switzerland. These sandstones contain abundant ophiolite detritus from the western Prealps with several Cr-bearing mineral phases (spinel, pyroxene, etc., Allen et al. 1985). Weathering of these minerals releases $\mathrm{Cr}$ into the groundwater, where it is present as highly soluble and mobile chromate anions $\left(\mathrm{Cr}^{\mathrm{VI}} \mathrm{O}_{4}{ }^{2-}\right)$. Because of the oxidising and neutral to alkaline $\mathrm{pH}$ conditions, reduction of $\mathrm{Cr}^{\mathrm{VI}}$ to $\mathrm{Cr}^{\mathrm{III}}$ does not occur, and therefore no solubility control by poorly soluble $\mathrm{Cr}^{\mathrm{III}}$-hydroxide occurs. In the Subalpine and folded molasse units, barite fracture mineralisation is the source of elevated Ba concentrations in associated groundwaters. In the "Glimmersand-Formation", granite detritus containing sulphides, $\mathrm{U}$ minerals and abundant mica leads to elevated Mo, U, and $\mathrm{Li}$ contents in the groundwater. Finally, the dissolution of evaporite minerals (Li, Sr), sulphides (Mo), and U minerals (U) lead to the special trace element content in groundwaters from the "Gypsumbearing molasse".

The short residence time and consequently poor chemical evolution of recent flysch groundwaters is one reason for their low trace element contents. In addition, the flysch rocks lack particular fracture mineralisations that could mark the groundwater circulating in these 


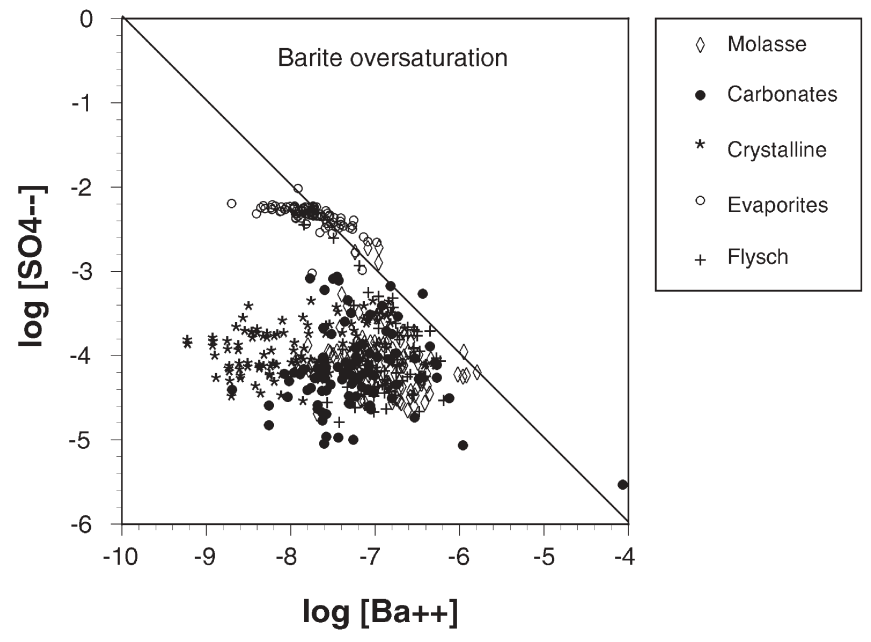

Fig. 9 Comparison of the calculated barite solubility in $\mathrm{SO}_{4}{ }^{2-}$-poor groundwaters and in $\mathrm{SO}_{4}{ }^{2-}-$ rich groundwaters (values plotted are activities)

fractures. The only exception is locally occurring barite, which results in elevated $\mathrm{Ba}$ contents in some of the recent flysch groundwaters. Lead concentrations of up to $6.3 \mu \mathrm{g} / \mathrm{L}$ occur in some recent carbonate karst and flysch groundwaters. These maximum concentrations lie in the same range as in precipitation (Table 3, Fig. 4). In addition, leaching experiments with carbonate and flysch aquifer rock material did not reveal any detectable $\mathrm{Pb}$ in the leachate solution, indicating that there is no readily soluble source of $\mathrm{Pb}$ in these aquifer types (note that $\mathrm{Pb}$ has not been analysed in crystalline and evaporite aquifer groundwaters). This suggests that in these fast circulating groundwaters most of the $\mathrm{Pb}$ is derived from the atmosphere.

In this group of recent groundwaters, $\mathrm{Ba}$ is a widespread trace element. The comparison of the calculated barite solubility to the $\mathrm{Ba}^{2+}$ and $\mathrm{SO}_{4}{ }^{2-}$ activities present in the groundwaters shows that high barium concentrations can only occur in $\mathrm{SO}_{4}{ }^{2-}$-poor groundwaters, as illustrated in Fig. 9. In $\mathrm{SO}_{4}{ }^{2-}$ - rich groundwater, only small amounts of barite can be dissolved before saturation is attained.

\section{Recent Groundwaters from Evaporite Rock Catchments}

In spite of their short residence time, evaporite-rock groundwaters are by far the most mineralised waters of all the investigated groundwaters. This is explained by the high solubility of gypsum and anhydrite (reactions 2 and $3)$. Calculations showed that in pure water at $20^{\circ} \mathrm{C}$, gypsum is about 225 times more soluble than calcite and 167 times more soluble than dolomite. Evaporite rocks commonly contain carbonate minerals and gypsum/ anhydrite dissolution is accompanied by calcite and dolomite dissolution according to reactions (1) and (8). These four reactions are linked to each other in the following way : The dissolution of gypsum/anhydrite releases abundant $\mathrm{Ca}^{2+}$ into the groundwater, so that equi- librium with calcite is rapidly reached, while gypsum/ anhydrite are still undersaturated. Ongoing gypsum/anhydrite dissolution will thus induce calcite precipitation. Calcite precipitation decreases the $\mathrm{CO}_{3}{ }^{2-}$ activity in the groundwater, thereby provoking further dissolution of dolomite and a resulting increase in $\mathrm{Mg}^{2+}$ concentration, according to

$$
\begin{aligned}
1.8 \mathrm{CaSO}_{4(\mathrm{~s})} & +0.8 \mathrm{CaMg}\left(\mathrm{CO}_{3}\right)_{2(\mathrm{~s})} \Leftrightarrow 1.6 \mathrm{CaCO}_{3(\mathrm{~s})}+\mathrm{Ca}^{2+} \\
& +0.8 \mathrm{Mg}^{2+}+1.8 \mathrm{SO}_{4}^{2-}
\end{aligned}
$$

This process is known as de-dolomitisation and was described for various dolomite-bearing evaporite aquifers and gypsum-bearing carbonate aquifers (Back and Hanshaw 1970; Wigley 1973; Back et al. 1984; Plummer et al. 1990). Mass balance calculations confirm that dedolomitisation takes place in the present evaporite-rock groundwaters (Table 5).

The concentrations of $\mathrm{Na}^{+}$and $\mathrm{K}^{+}$are generally low in the evaporite-rock groundwaters (Table 3). Only in a few cases the $\mathrm{Cl}^{-}$contents are significantly higher than in infiltrating precipitation water and $\mathrm{Na}^{+}$and $\mathrm{K}^{+}$contents appear to be derived from $\mathrm{Cl}$-salts (e.g. halite, silvite, carnallite). In most evaporite-rock waters, however, $\mathrm{Cl}$ contents are only slightly higher than in infiltrating precipitation and possible sources for $\mathrm{Na}$ and $\mathrm{K}$ include ion exchange with clay minerals or dissolution of sulphate salts (e.g. glauberite, polyhalite, bloedite, langbeinite) locally present in such rocks. However, this cannot be resolved based on the groundwater composition alone and mass balance calculations show that the small mass transfer (i.e. ion exchange in Table 5) required to obtain the observed concentrations would not alter the general reaction pattern.

During evaporation of sea or fresh water a large variety of trace element bearing accessory minerals form (e.g. chloride and sulphate salts, carbonates, phosphates), most of which are highly soluble. In addition, trace elements are incorporated as solid solutions into major mineral phases. While the concentrations of dissolved $\mathrm{Sr}^{2+}, \mathrm{Ba}^{2+}$, $\mathrm{F}^{-}$and silica can be associated mainly with the dissolution of mineral phases such as celestite, barite, fluorite, and quartz, other elements present at characteristically elevated concentrations, including $\mathrm{Mn}, \mathrm{Ni}, \mathrm{Cu}, \mathrm{Li}, \mathrm{Rb}$, and $\mathrm{Cd}$, can originate from multiple sources. $\mathrm{Mn}, \mathrm{Ni}, \mathrm{Cd}$, and $\mathrm{Cu}$ can be derived from dissolution of carbonates and oxidation of sulphides (present in argillaceous layers), $\mathrm{Cd}$ from phosphates, and $\mathrm{Li}$ and $\mathrm{Rb}$ from brine fluid inclusions. Desorption processes may also be involved for all of these elements. Complexation of metal ${ }^{2+}$ ions such as $\mathrm{Mn}^{2+}, \mathrm{Ni}^{2+}$ and $\mathrm{Cu}^{2+}$ with the major anions $\mathrm{SO}_{4}{ }^{2-}$ and/or $\mathrm{CO}_{3}{ }^{2-}$ decreases their activity and thus leads to an increased undersaturation with the corresponding oxide or hydroxide phase. The solubility of these elements is thus enhanced by complexation. Lithium and rubidium are both highly soluble and chemically conservative elements, and there seems to be no mechanism that removes significant amounts of $\mathrm{Li}$ or $\mathrm{Rb}$ from solution. 
Table 6 Summary of natural tracers in recent groundwaters from different aquifer types. The concentrations of these elements can serve as georeference (natural background concentrations) for such groundwaters

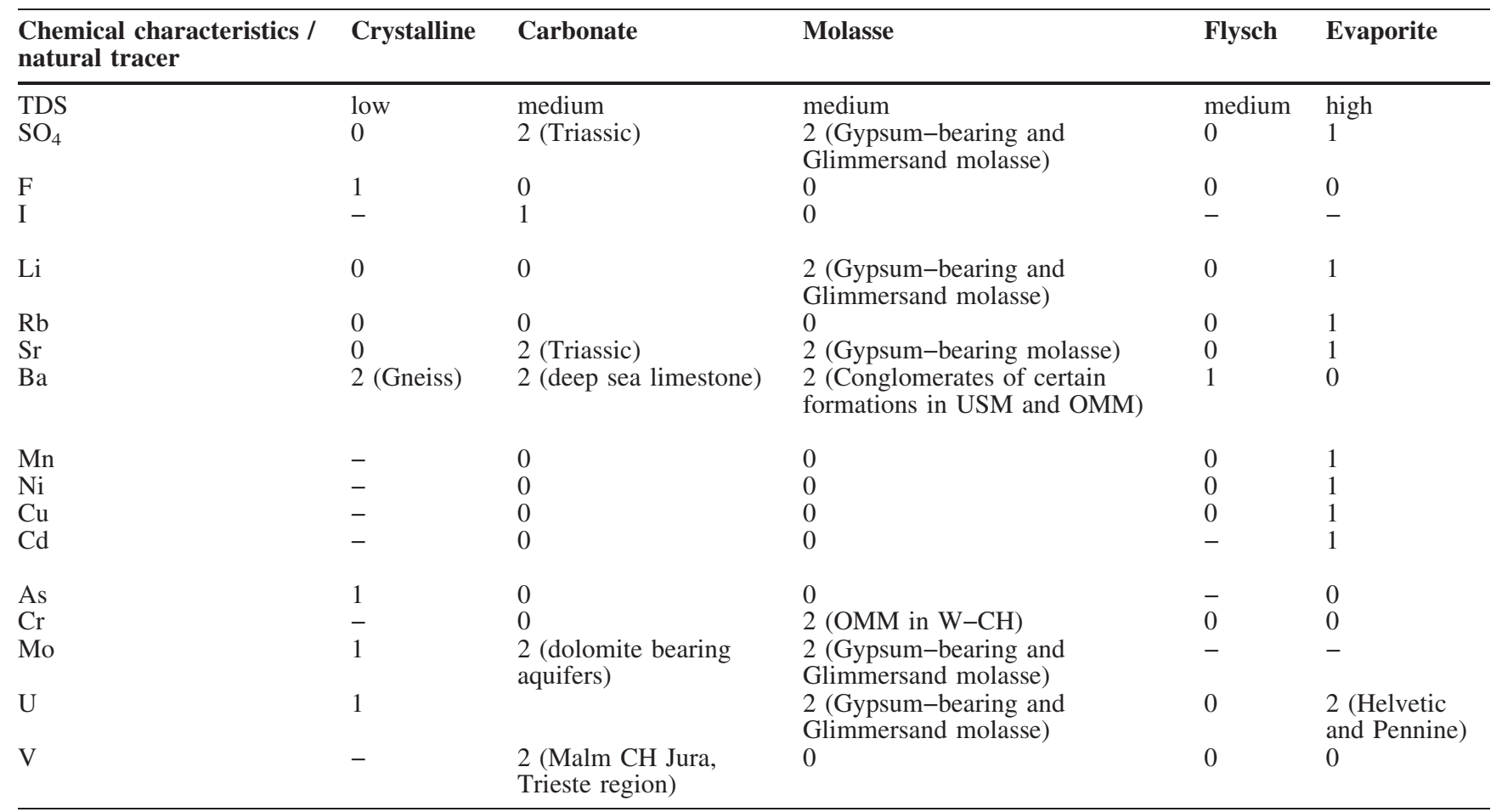

0: not indicative as tracer; 1 : highly indicative; 2 : indicative for specific rock types / formations within an aquifer type; -: no data; USM: Lower Freshwater Molasse; OMM: Upper Marine Molasse; W-CH: western Switzerland

\section{Conclusions}

Groundwaters from different aquifer types with residence times between days and a few years (so-called recent groundwaters) show characteristic signatures in major element composition and in the degree of mineralisation. Based on these signatures, recent groundwaters from crystalline-rock aquifers, carbonate-rock and calcareous clastic-sediment aquifers and evaporite-rock aquifers can be clearly distinguished. Recent groundwaters from carbonate karst and calcareous clastic-sediment aquifers (Molasse and Flysch units), however, are all of a similar $\mathrm{Ca}-(\mathrm{Mg})-\mathrm{HCO}_{3}$ chemical type with similar total mineralisation. To distinguish such groundwaters derived from different lithologic environments, trace elements prove to be useful. It is shown that certain natural trace elements are present in concentration ranges that are characteristic for groundwaters from different aquifer rock formations on a local and on a regional scale. In Table 6 a summary of these natural tracers is given.

The chemical evolution of groundwaters from five different aquifer types is quantitatively described by modelling the interaction of the groundwater with minerals present along the flow path. The observed concentration ranges of major and trace elements therefore represent natural background concentrations and can serve as a "geo-reference" for such groundwaters from hydrogeologically different environments. This geo-reference can be particularly useful for the identification of groundwater contamination. It is shown that WHO drinking water standards can be grossly exceeded for critical elements (e.g. F, As) by purely natural processes. This clearly supports the conclusion that effective groundwater management and quality assessment cannot be made without a comprehensive knowledge of the groundwater chemistry, geology and hydrology of a catchment. In addition, with its characteristic chemical information about the recharge environment of infiltrating groundwater, the geo-reference can be of potential use to flow path identification and thus to water management in underground works (e.g. tunnel construction). The dependence of the major and trace element composition on reaction kinetics (and thus groundwater residence time) and on mineral occurrence allows one to clearly distinguish between systems dominated by fracture flow, such as the aquifers in the crystalline, and systems with combined matrix and fracture flow, such as the molasse aquifers, where the specific trace element concentrations partly result from the dissolution of minerals disseminated in the matrix. The chemical composition of recent groundwaters from different aquifer types therefore also contains certain information about the governing groundwater flow regime in a catchment.

Acknowledgements The linguistic review of the manuscript by Monique Y. Hobbs (Rock-Water Interaction, Institute of Geological Sciences, University of Bern) is greatly acknowledged. Review comments made by Dr. S. Dogramaci and Prof. Y. Travi helped to 
improve the clarity of the manuscript and are highly appreciated. This study was financially supported by the Swiss National Science Foundation (Grant No20-45730.95).

\section{References}

Adriano DC (1986) Trace elements in the terrestrial environment. Springer, Heidelberg Berlin New York

Appelo CAJ, Postma D (1996) Geochemistry, Groundwater and Pollution. Balkema, Rotterdam, Brookfield

Allen PA, Mange-Rajetzky M, Matter A, Homewood P (1985) Dynamic palaeogeography of the open Burdigalien seaway, Swiss Molasse Basin. Eclogae Geol Helv 78:351-381

Atkinson TC (1975) Diffuse flow and conduit flow in limestone terrain in the Mendip Hills, Sommerset, England. In: IAH Congress, Huntville, Alabama

Atteia O (1992) Rôle du sol dans le transfert des elements traces en solution - Application à l'étude de quelques écosystems d'altitude. (The role of the soil in the transport of dissolved trace elements-Application to different Alpine ecosystems) $\mathrm{PhD}$, Federal Institute of Technology Lausanne, Switzerland

Atteia O (1994) Transport of major and trace elements in soils and aquifers of different ecosystems of Switzerland. Eclogae Geol Helv 87:409-428

Back W, Hanshaw BB (1970) Comparison of chemical hydrogeology of the carbonate peninsula of Florida and Yucatan. Journal of Hydrology 10:330-368

Back W, Hanshaw BB, Plummer, LN, Rahn PH, Rightmire CT, Rubin M (1984) Process and rate of dedolomitisation: mass transfer and C14 dating in a regional carbonate aquifer. Geol Soc Am Bull 95:1,415-1,429

Ball JW, Nordstrom DK (1991) WATEQ4F — User's manual with revised thermodynamic data base and test cases for calculating speciation of major, trace and redox elements in natural waters. US Geological Survey Open-File Report 90-129

Basabe PP (1993) Typologie des eaux souterraines du flysch de la nappe tectonique du Niesen (Préalpes Suisses). [Typology of groundwaters derived from the flysch of the Niesen tectonic nappe (Swiss Prealps)] PhD, Federal Institute of Technology Lausanne, Switzerland

Blum JD, Gazis CA, Jacobson AD, Chamberlain CP (1998) Carbonate versus silicate weathering in the Raikhot watershed within the high Himalayan crystalline series. Geology 26:411414

Bundesamt für Umwelt, Wald und Landschaft (BUWAL) (1998) Nationale Grundwasserqualitätsbeobachtung (NAQUA). [National groundwater quality monitoring (NAQUA)] Bern, Switzerland

Church TM (1979) Marine barite. In: Burns RG (ed) Marine Minerals. Min Soc Am Reviews in Mineralogy 6:175-209

Dalla Piazza R (1996) Géochimie des altérations dans trois écosystèmes de sol tempérés - Application à l'acquisition des caractéristiques chimiques des solutés. (Geochemistry of mineral weathering in three temperate soil ecosystems - Characterisation of dissolved constituents.) PhD, Federal Institute of Technology Lausanne, Switzerland

Dematteis A (1995) Typologie géochimique des eaux des aquifères carbonatés des chaînes alpines d'Europe centrale et méridionale. (Geochemical typology of groundwaters derived from Alpine carbonate-rock aquifers of central and southern Europe.) $\mathrm{PhD}$, Federal Institute of Technology Lausanne, Switzerland

Dreybrodt W (1998) Limestone dissolution rates in karst environments. Bulletin d'Hydrogéologie 16:167-183

Dubois J-D (1993) Typologie des aquifères du cristallin: Exemple des massifs des Aiguilles Rouges et du Mont Blanc (France, Italie et Suisse). [Typology of crystalline-rock aquifers: Example of the Aiguilles Rouges and Mont Blanc massifs (France, Italy and Switzerland).] PhD, Federal Institute of Technology Lausanne, Switzerland
Ford DC (1998) Perspectives in karst hydrogeology and cavern genesis. Bulletin d'Hydrogéologie 16:9-29

Ford DC, Williams P (1989) Karst Geomorphology and Hydrology, Unwin Hyman, London

Frapporti G, Vriend SP, Van Gaans PFM (1996) Trace elements in the shallow groundwater of the Netherlands. A geochemical and statistical interpretation of the National Monitoring Network data. Aquatic Geochemistry 2:51-80

Greber E, Baumann A, Cornaz S, Herold T, Kozel R, Muralt M, Zobrist J (2002) Grundwasserqualität der Schweiz. (Groundwater quality in Switzerland) GWA, 3:191-201(in German)

Harris N, Bickle M, Chapman H, Fairchild I, Bunbury J (1998) The significance of Himalayan rivers for silicate weathering rates: evidence from the Bhote Kosi tributary. Chem Geol 144:205220

Hesske S (1995) Typologie des eaux souterraines de la Molasse entre Chambéry et Linz (France, Suisse, Allemagne, Autriche). [Typology of groundwaters derived from molasse aquifers between Chambéry and Linz (France, Switzerland, Germany, Austria)] $\mathrm{PhD}$, Federal Institute of Technology Lausanne, Switzerland

Hesske S, Parriaux A, Bensimon B (1997) Geochemistry of springwaters in Molasse aquifers: Typical mineral trace elements. Eclogae Geol Hel 90:151-171

Holser WT (1979a) Mineralogy of evaporites. In: Marine Minerals. Min Soc Am Reviews in Mineralogy 6:211-294

Holser WT (1979b) Trace elements and isotopes in evaporites. In: Marine Minerals. Min Soc Am Reviews in Mineralogy 6:295346

Jäckli H (1970) Kriterien zur Klassifikation von Grundwasservorkommen. (Criteria for groundwater classification) Eclogae Geol Helv 63:389-434

Kilchmann S (2001) Typology of Recent Groundwaters from Different Aquifer environments Based on Geogenic Tracer Elements. PhD, Federal Institute of Technology Lausanne, Switzerland

Lebdioui S, Michelot J-L, Fontes J-CH (1990) Origine de la minéralisation sulphatée et carbonatée des eaux du tunnel sous le Mont-Blanc. (Origin of the sulphate and carbonate mineralisation of groundwaters discharging in the Mont-Blanc road tunnel.) In: A. Parriaux (ed) Proceedings of the $22^{\text {nd }}$ Congress of IAH: Water Resources in Mountainous Regions 1:496-503

Mandia Y (1993) Typologie des aquifères évaporitiques du Trias dans le Bassin lémanique du Rhône (Alpes occidentales). [Typology of Triassic evaporite-rock aquifers in the Swiss Rhône Valley (western Alps)] PhD, Federal Institute of Technology Lausanne, Switzerland

Maréchal JC (1998) Les circulations d'eau dans les massifs cristallins alpins et leurs relations avec les ouvrages souterrains. (Groundwater flow in Alpine crystalline-rock massifs and its implications for underground construction.) $\mathrm{PhD}$, Federal Institute of Technology Lausanne, Switzerland

Markert B, Friese K (eds) (2000) Trace elements - Their distribution and effects in the environment. Elsevier, Amsterdam.

Martin JB, Gieskes JM, Torres M, Kastner M (1993) Bromine and iodine in Peru margin sediments and pore fluids: Implications for fluid origin. Geochim Cosmochim Acta 57:4,377-4,389

Moore WS, Ramamoorthy J (1984) Heavy metals in natural waters: applied monitoring and impact assessment. Springer, Heidelberg Berlin New York

Nriagu JO (1991) Trace metals in the environment, Elsevier, Amsterdam

Parkhurst DL, Appelo CAJ (1999) User's guide to PHREEQC (version 2) - a computer program for speciation, batch reaction, one-dimensional transport, and inverse geochemical calculations. US Geol Survey Water-Resources Investigations Report 99-4259

Parriaux A (1981) Contribution à l'étude des ressources en eau du bassin de la Broye. (Contribution to the study of water resources in the Broye basin.) $\mathrm{PhD}$, Federal Institute of Technology Lausanne, Switzerland 
Parriaux A, Dubois J-D, Mandia Y, Basabe P, Bensimon M (1990a) The AQUITYP Project: Towards an aquifer typology in the alpine orogen. In: Parriaux A (ed.) Proceedings of the $22^{\text {nd }}$ Congress of IAH: Water Resources in Mountainous Regions $1: 254-262$

Parriaux A, Mayoraz R, Mandia Y (1990b) Impact assessment of deep underground works on a mineral water resource in an alpine evaporitic context. In: Parriaux A (ed) Proceedings of the $22^{\text {nd }}$ Congress of IAH: Water Resources in Mountainous Regions 2:1,249-1,258

Pfeifer H-R, Hansen J, Hunziker J, Rey D, Schafer M, Serneels V (1995) Arsenic in Swiss soils and waters and their relation to rock composition and mining activities. In: $3^{\text {rd }}$ Int Conf on the Biogeochemistry of Trace Elements, Paris

Pfeifer H-R, Derron M-H, Rey D, Schlegel C, Atteia O, Dalla Piazza R, Dubois J-D, Mandia Y (2000) Natural trace element input to the soil-sediment-water-plant system: examples of background and contaminated situations in Switzerland, Eastern France and Northern Italy. In: Markert B, Friese K (eds) Trace elements - Their distribution and effects in the environment. Elsevier, Amsterdam.

Piper AM, Garret AA (1953) Native and contaminated groundwaters in the Long Beach-Santa Ana area, California. US Geol Survey Water Supply Paper 1,136

Plummer LN, Back W (1980) The mass balance approach: Application to interpreting the chemical evolution of hydrologic systems. Amer J Sci 280:130-142

Plummer LN, Busby JF, Lee RW, Hanshaw BB (1990) Geochemical Modelling of the Madison Aquifer in Parts of Montana, Wyoming, and South Dakota. Water Resources Research $26: 1,981-2,014$
Plummer LN, Prestemon EC, Parkhurst DL (1994) An interactive code (NETPATH) for modelling NET geochemical reactions along a flow PATH, version 2.0. US Geol Survey WaterResources Investigations Report 94-4169

Sahu SJ, Roy S, Jana J, Nath B, Bhattacharya R, Chatterjee D, Dey Dalal SS (2001) Water chemistry and sediment-water interaction responsible for the mobilisation of arsenic in groundwater in Bengal delta plain. In: Cidu R (ed) Proc. of the $10^{\text {th }}$ Int Symp on Water-Rock Interaction-WRI-10, A. A. Balkema, Lisse, The Netherlands, pp 1,139-1,142

Salomons W, Förstner U (1984) Metals in the Hydrocycle. Springer, Heidelberg Berlin New York

Schoepfer P (1989) Sédimentologie et stratigraphie de la Molasse marine supérieure entre le Gibloux et l'Aare. (Sedimentology and stratigraphy of the Upper Marine Molasse between the Gibloux and the Aare river) $\mathrm{PhD}$, University of Fribourg, Switzerland

Trümpy R (1980) Geology of Switzerland, A Guide Book. Wepf, Co., Basel, New York

Wedepohl KH (1978) Handbook of Geochemistry. Springer, Heidelberg Berlin New York

White AF, Bullen TD, Vivit DV, Schulz MS, Clow DW (1999) The role of disseminated calcite in the chemical weathering of granitoid rocks. Geochim Cosmochim Acta 63:1,939-1,953

Word Health Organisation (WHO) (1993) Guidelines for drinkingwater quality. Recommendations. $\left(2^{\text {nd }}\right.$ ed). Geneva

Word Health Organisation (WHO) (1998) Guidelines for drinkingwater quality. Recommendations. ( $2^{\text {nd }}$ ed). Geneva

Wigley TML (1973) The incongruent dissolution of dolomite. Geochim Cosmochim Acta 37:1,397-1,402 